\title{
Un casco variante del grupo Italo-Calcídico en la Necrópolis de Los Canónigos, Arcas del Villar (Cuenca).
}

\author{
Fernando QUESADA SANZ \\ Universidad Autónoma de Madrid \\ Miguel Ángel VALERO TÉVAR \\ Universidad de Castilla-La Mancha
}

\section{Resumen}

Este artículo ofrece un estudio detallado del casco hallado en la Tumba 3 de la necrópolis ibérica de 'Los Canónigos' (Arcas del Villar, Cuenca), y del resto del ajuar de la sepultura. Se trata del único ejemplar casi completo de casco de una variante hispana del tipo calcídico o italo-calcídico, descubierto con un contexto arqueológico preciso. Se propone su denominación como hispano-calcídico, y una horquilla máxima para este ejemplar de entre la segunda mitad del s. IV y principios del s. II a.C., y una más probable de los comienzos del s. III a.C., y en todo caso antes de la presencia romana en la Península Ibérica y antes de la penetración militar de los Barca a fines del s. III a.C. con lo que ello significa en tanto que implica un conocimiento previo de los prototipos greco-itálicos muy anterior a esos momentos.

Palabras clave: Cultura Ibérica. Necrópolis. Casco italo-calcídico. Casco hispano-calcídico

\section{Summary}

This paper presents a detailed study of the helmet found in Burial 3 in the Iberian Iron Age cemetery at 'Los Canónigos', (Arcas del Villar, Cuenca, Spain), and also of the other grave goods found with it in the burial. It is the only almost complete example of a helmet of a peculiarly Spanish variant of the Chalcidian or Italo-Chalcidian type found in a precise archaeological context. We propose its definition as a Spanish-Chalcidian type, and a chronology for this example between the second half of the 4th c. BC and the early part of the 2nd c. BC (long span) and probably in the early 3rd c BC (short time-span). This means that the helmet was manufactured in the Peninsula long before the Roman presence and even before the military conquest by the Barquids at the end of the 3rd c. BC. This implies an early knowledge of the Graeco-Italic prototypes long before these events.

Keywords: Iberian Iron Age. Cemetery. Italo-Chalcidic helmet. Hispano-Chalcidic Helmet.

\section{INTRODUCCIÓN}

La construcción de la Línea ferroviaria de Alta Velocidad Madrid/Castilla-La Mancha /Comunidad Valenciana/Región de Murcia, en su tramo Arcas del Villar/ Fuentes (Cuenca), motivó la intervención del yacimiento de Los Canónigos, del que fue excavada la superficie de terreno incluida en la banda de afección de las obras inherentes a la infraestructura.

Las limitaciones impuestas por el proyecto constructivo impidieron la excavación completa del enclave. Solo se ha intervenido pues sobre una pequeña parte del mismo, lo cual distorsiona inevitablemente nuestro conocimiento y la capacidad de interpretación global 
del yacimiento. Pese a ello, se pudo documentar un área reducida de la última fase de ocupación del poblado, que cuenta con tres fases constructivas de compleja compartimentación y grandes dimensiones (Valero, 2012a: 137; 2012b: passim), así como diversas estructuras adscritas al primer momento de hábitat en el mismo. Además se descubrió y excavó en 2007 una pequeña parte de la necrópolis usada por los moradores del asentamiento en su etapa final, si bien para la ejecución de algunas de las tumbas reutilizaron elementos de la fase anterior, como restos de escultura que, como en otros casos, intencionadamente deteriorados (Chapa, 1993: 186; Blánquez, 1999: 63)

\section{LOCALIZACIÓN}

El yacimiento de Los Canónigos se sitúa en la parte central del actual término municipal de Arcas del Villar (Cuenca), inserto en un territorio en el que los estudios superficiales (Valero, 2007: 215 ss.) confirman una alta densidad de poblamiento de cronología ibérica, con asentamientos de grandes dimensiones como Los Gamellones, Los Villares, Cerro de la Estrella, etc., así como otros de menor tamaño.

Se ubica en la parte baja de una suave ladera orientada al sur, que bascula hacia el margen derecho del río San Martín, anejo a su ámbito de influencia.

El paisaje actual circundante se caracteriza por la alternancia de espacios llanos, cerros de elevación media y baja entre los que discurren diversos cauces fluviales de irregular caudal y encajados valles, como las denominadas Hoces. Los altozanos, en concordancia con la comarca natural en la que se encuentran (la Serranía Baja Conquense,) suelen estar ocupadas por pinos y monte bajo junto a encinas y robles, vegetación de idóneas condiciones para el pastoreo, mientras que en los valles se han mantenido algunas choperas, habiendo sido en su mayor parte muy transformados por el laboreo agrícola.

Geológicamente las elevaciones circundantes están formadas por calizas y gravas, mientras que las zonas bajas, se componen básicamente por arcillas y depósitos sedimentarios del cuaternario, procedentes principalmente de los aluviones de las cárcavas que confluyen en el valle del río San Martín. Las características geológicas, hacen que los suelos cuenten con un alta fertilidad, lo que unido a un clima adecuado, conjugan unas adecuadas condiciones para la explotación agrícola, hecho que probablemente no haya cambiado desde épocas pretéritas.

Precisamente esas características que facilitan la sobreexplotación actual de la tierra, hacen que resulte complicado delimitar con exactitud las dimensiones totales del yacimiento fuera del ámbito de la excavación realizada, ya que su ubicación en la ladera media y baja favorece la aportación natural de tierras desde las zonas altas y medias de la loma ocultando las evidencias superficiales, al tiempo que los trabajos de laboreo agrícola han provocado la dispersión del material detectado en superficie.

\section{LA NECRÓPOLIS}

Tal y como hemos apuntado antes, los límites impuestos por el proyecto constructivo del ferrocarril condicionan en gran medida la obtención de determinados resultados, siendo un ejemplo elocuente la imposibilidad de conocer las dimensiones totales del cementerio. Nos encontramos ante una información parcial, pues la excavación de la necrópolis se limita a una superficie de 352 $\mathrm{m}^{2}$, sin que podamos por ahora determinar a qué proporción del total del complejo funerario corresponde.

Pese a lo reducido del área excavada, resulta destacable la existencia de un murete situado al noroeste, realizado mediante doble hilada de mampostería careada/ que podría responder a uno de los límites físicos del cementerio, que habría estado así limitado y definido por un peribolos, tal y como ocurre en otros casos (Blánquez, 1990a: 409; 1992:250; 1993:114; 1995:252; Valero, 1999:186; 2005:321; 2010b:1016), aunque esta posibilidad no se ha podido demostrar.

Al contrario que en el poblado asociado (Valero, 2010a:162; 2012a:213), en la necrópolis se ha documentado una única etapa de 
uso, datada probablemente entre los siglos IV y III a.C., si bien su lapso de utilización es dilatado en el tiempo contando cada tumba con su cronología específica. Los impedimentos de la intervención en una superficie reducida, junto al hecho de que su uso responde a un único momento, determina la inexistencia de estratigrafía superpuesta físicamente, al contrario de lo que parece ocurrir en otros cementerios cercanos como en Iniesta al sur/sureste (Valero 1999a:181;
2005:320; 2010c:1012 ); en El Navazo al suroeste (Galán 1980, 145), en Alconchel de la Estrella al suroeste (Millán 1988:403; 1990:198; 1995:247); o en Buenache de Alarcón al sur (Losada 1960:159).

Pese a que solo se han podido exhumar siete tumbas, podemos concluir que se trata de un cementerio en el que los tipos de tumbas resultan bastante heterogéneos, con variaciones tipológicas importantes (Figura 1)

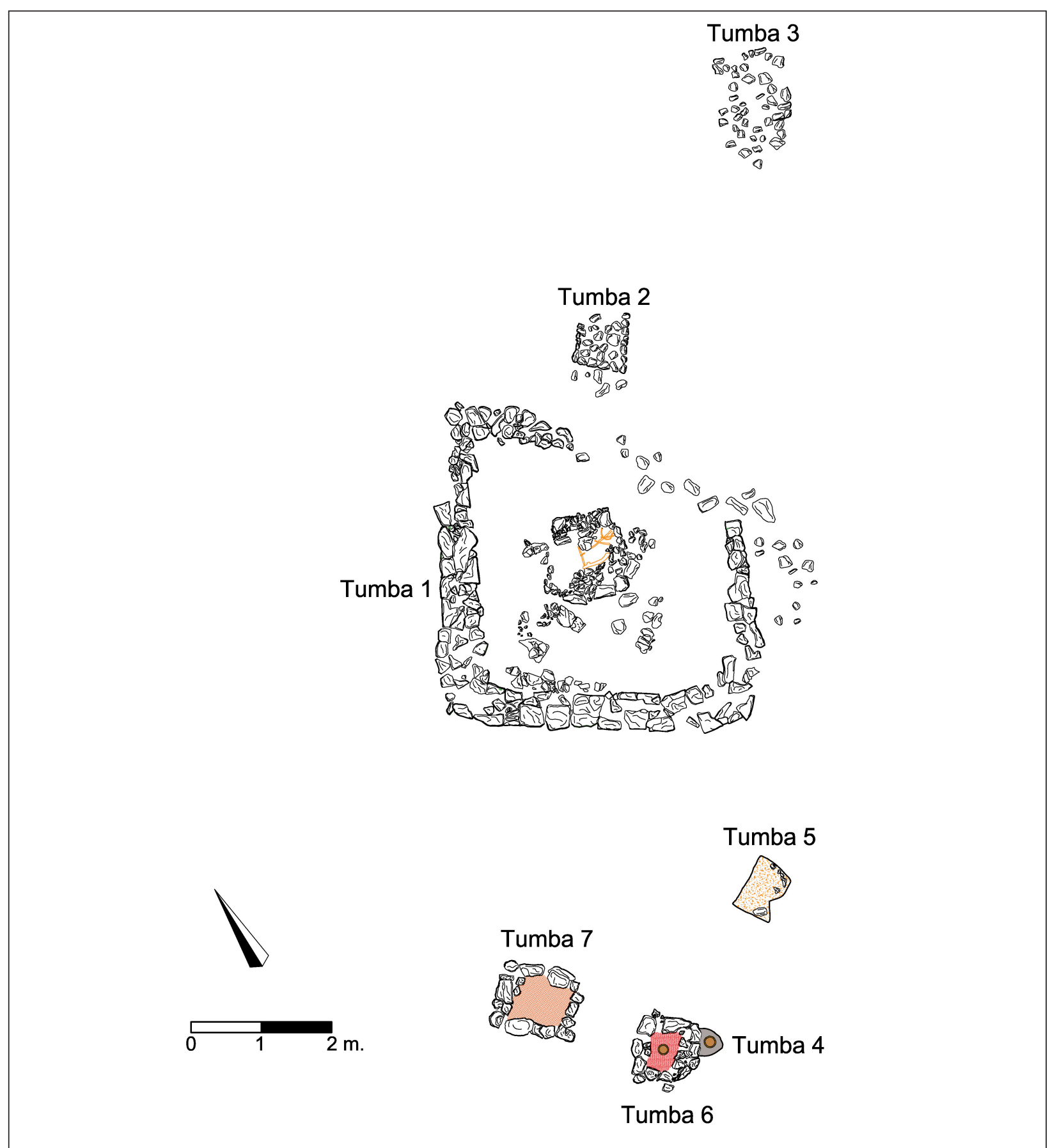

Figura 1.- Plano general de la zona excavada de la necrópolis de Los Canónigos (Arcas del Villar, Cuenca) 
El tipo de sepultura más sencillo es la incineración en hoyo con urna cineraria como elemento contenedor de los restos óseos. Otra forma de enterramiento documentada en Los Canónigos consiste en un receptáculo de forma cuadrangular excavado en el terreno y delimitado por piedras de distinto tamaño sin desbastar. Estas fueron colocadas buscando cierta orientación en el sentido de los puntos cardinales, no llegando a tocar la urna, pero cumpliendo una función protectora de la misma, ya que palian la presión ejercida por la tierra. Una tercera forma de enterramiento es aquella en la que el receptáculo realizado en la tierra y que conforma la tumba propiamente dicha, es cubierto por un cerramiento de adobes que cumple la doble función de sellado e indicación de la tumba en la necrópolis. El cuarto tipo son estructuras tumulares realizadas con mampostería, como en otras necrópolis (Aranegui, 1992:171; Blánquez, 1988:347; Cuadrado, 1987:155; Valero, 1999:191), que están orientadas casi, en sentido de los puntos cardinales, con unas dimensiones medias ligeramente superiores al metro de lado.

Destaca estructuralmente la Tumba 1, un pequeño túmulo cuadrangular de poco más de 1,20 m. de lado, que emplea piedras junto a restos escultóricos pertenecientes a una primera fase de uso del cementerio que no ha sido documentada en la excavación (Valero, 2010a:164; 2012a:178). Cuenta con un murete que lo delimita formando un recinto cuadrangular de $4,50 \mathrm{~m}$. de lado, realizado completamente con paramento de doble fila de mampostería y que no se elevaría más de $0,50 \mathrm{~m}$. sobre el nivel de suelo.

La estratigrafía que cubría el recinto funerario está formada por varias unidades compuestas por aportaciones naturales de tierras procedentes de la ladera alta y media, alternando con niveles de limos y lodos originados por aluviones, siendo éstos los responsables del sellado de la necrópolis. Todos ellos fueron cubiertos por la capa de tierra aportada por el arado.

\section{Algunas Cuestiones de atribución CULTURAL}

El carácter fronterizo de la zona conquense, entre la Celtiberia y el ámbito ibérico, es reconocido desde hace mucho (e.g. Almagro Gorbea 1976-78) y trabajos recientes mucho más específicos lo confirman (Almagro Gorbea, 1999; Lorrio 1999a, 1999b, 2007), y es en este contexto fronterizo de intensa relación e intercambio de materiales en el que debe entenderse lo que sigue.

No es este el lugar para abordar un estudio detallado de los materiales de la necrópolis, y en particular de los relativamente abundantes conjuntos metálicos (Valero 2012a) pero en conjunto, puede afirmarse que las armas, fíbulas, etc. de la necrópolis son consistentes con un entorno ibérico del sureste peninsular (mitad meridional de las actuales provincias de Cuenca y Valencia, y las provincias actuales de Albacete $\mathrm{y}$ Murcia). Así, en lo que se conoce, no aparecen espadas de hoja recta con empuñadura de antenas o de frontón, ni moharras de lanza con secciones en arista o lenticulares ni base ancha, ni otros elementos muy característicos de la Meseta Oriental celtibérica. Lo mismo ocurre con la cerámica, que es básicamente de tipo ibérico (Valero 2012a).

En la Sep. 6 se documentó una falcata de tipo B (cabeza de caballo) sin especiales indicios que permitan afinar cronología, y una moharra de lanza de $38 \mathrm{~cm}$. de la variante VA, sección 1, Tipo 2a (aunque próximo al 5a), típica del s. IV a.C. aunque llega a la segunda mitad del s. III a.C. en yacimientos como Coimbra del Barranco Ancho (Sep. 51, Quesada cat. 1133; Sep. 58, cat. Quesada 5829) (García Cano et al. 2008).

En la Sep. 1, la más importante por su volumen y la presencia de fragmentos reutilizados de escultura, se ha documentado, entre otros materiales, una panoplia también típicamente ibérica del Sureste: falcata tipo C (empuñadura perdida parcialmente), soliferreum con empuñadura tipo $2 \mathrm{~b}$, de unos 180 $\mathrm{cm}$. de longitud o más, sin empuñadura definida en el centro (Quesada 1997), así como una punta de lanza fragmenta e incompleta de la Variante VIB. Además, se documenta un 
elemento de cabezada metálica rígida y un bocado de caballo de filete de embocadura articulada y camas curvas. La cronología, imprecisa, podría abarcar desde el s. IV hasta mediados del II a.C.

En la Sep. 3, por último, contamos con un casco de bronce y dos bocados de filete de camas curvas, de los que nos ocuparemos más adelante.

Dada la escasez habitual de arreos de caballo en necrópolis ibéricas, llama especial y notablemente la atención la presencia de varios arreos de caballo en la Sepulturas 1 y 3 de la necrópolis. Abundancia por cierto más propia del ámbito celtibérico que del ibérico ( $c f$. Quesada 1998:Fig. 4). El elemento de cabezada rígida metálica, una quijera, montante o carrillera en hierro con anillas en los extremos y ojal central, de la Sep. 1, es el más significativo. Contra lo que se ha escrito, se trata de una quijera y no un bocado, dato que se puede asegurar a partir de una pieza completa en el RGM de Mainz publicada por Schüle (1969:Abb. 13) (contra Cabré 1929:Lám. XVII). En todo caso, lo que aquí interesa es que el tipo se asocia tradicionalmente a la Meseta, y desde fases antiguas incluso desde muy principios del s. IV a.C., ya que aparece ya en Alpanseque, Aguilar de Anguita (tres ejemplares al menos), y perdura luego como en Carratiermes (Argente, Díaz, Bescós 2000:75 ss.; Altillo de Cerropozo (dos), (e.g. Schüle 1969) y otros muchos yacimientos meseteños (Lorrio 2005: Tablas 1-2). Sin embargo se documenta también en fases algo más tardías, como en Arcóbriga (dos ejemplares sin contexto preciso, $c f$. Lorrio, Sánchez 2000:272-273; 356-357) y sobre todo en Altillo de Cerropozo (Sep. 16), o Quintanas de Gormaz también en el s. III a.C. (subfase IIB de Lorrio 2005).

Pero el tipo no es necesaria ni exclusivamente 'celtibérico', ya que aparece también en el ámbito ibérico. Procedente de Andalucía se conoce uno de los ejemplares más antiguos, procedente de la Sep. 11 de
Galera en Granada (Cabré y Motes, 1920, Lám XIV; Pereira et al. 2004:82 ss.) fechada en la segunda mitad del s. V a.C., y también uno de los más tardíos (ejemplar, inédito, en el poblado del Cerro de la Cruz, Almedinilla, en un contexto bien fechado por material importado de c. 140 a.C.; campaña 2007, espacio XXI, UE 1111). El tipo de quijera rígida también aparece en el ámbito ibérico del Sureste, en Alicante (Serreta de Alcoy, Quesada 2002-3:97-98, ss. III-II a.C.). Por tanto la presencia de este montante rígido en Canónigos no puede emplearse a nuestro juicio para proponer cronología o adscripción cultural en un sentido u otro.

Los importantes fragmentos escultóricos reutilizados en la Sep. 1, por último, que incluyen figuras de guerreros y armas, son sin duda ibéricos, del tipo de los documentados en el área de Albacete/Murcia/ Alicante, como Porcuna o Elche, sin paralelos en el mundo meseteño (Valero 2012a).

En conjunto, pues, esta necrópolis, ubicada en una amplia área o franja fronteriza entre el ámbito de la cultura ibérica y la celtibérica meridional ( $c f$. Valero ed., 1999; Lorrio 1999a y b; 2001) parece bascular claramente hacia lo ibérico, pese a situarse al norte de la línea Segóbriga/Valeria/el Molón aunque sin duda, y precisamente con el carácter fronterizo de la región, cabe esperar materiales mezclados o de ambas procedencias.

\section{LA SEPULTURA 3 Y SU AJUAR}

Esta sepultura está formada por una fosa excavada en la roca (UE 73), de morfología oval con una orientación aproximada nortesur, con unas dimensiones de 0,78 x 0,70 $\mathrm{m}$., que contenía un estrato ceniciento (UE 72) con escasos restos óseos, algunos fragmentos cerámicos y un importante ajuar metálico, todo ello sellado por una capa de limos amarillentos, UE 71 (Figura 2) 


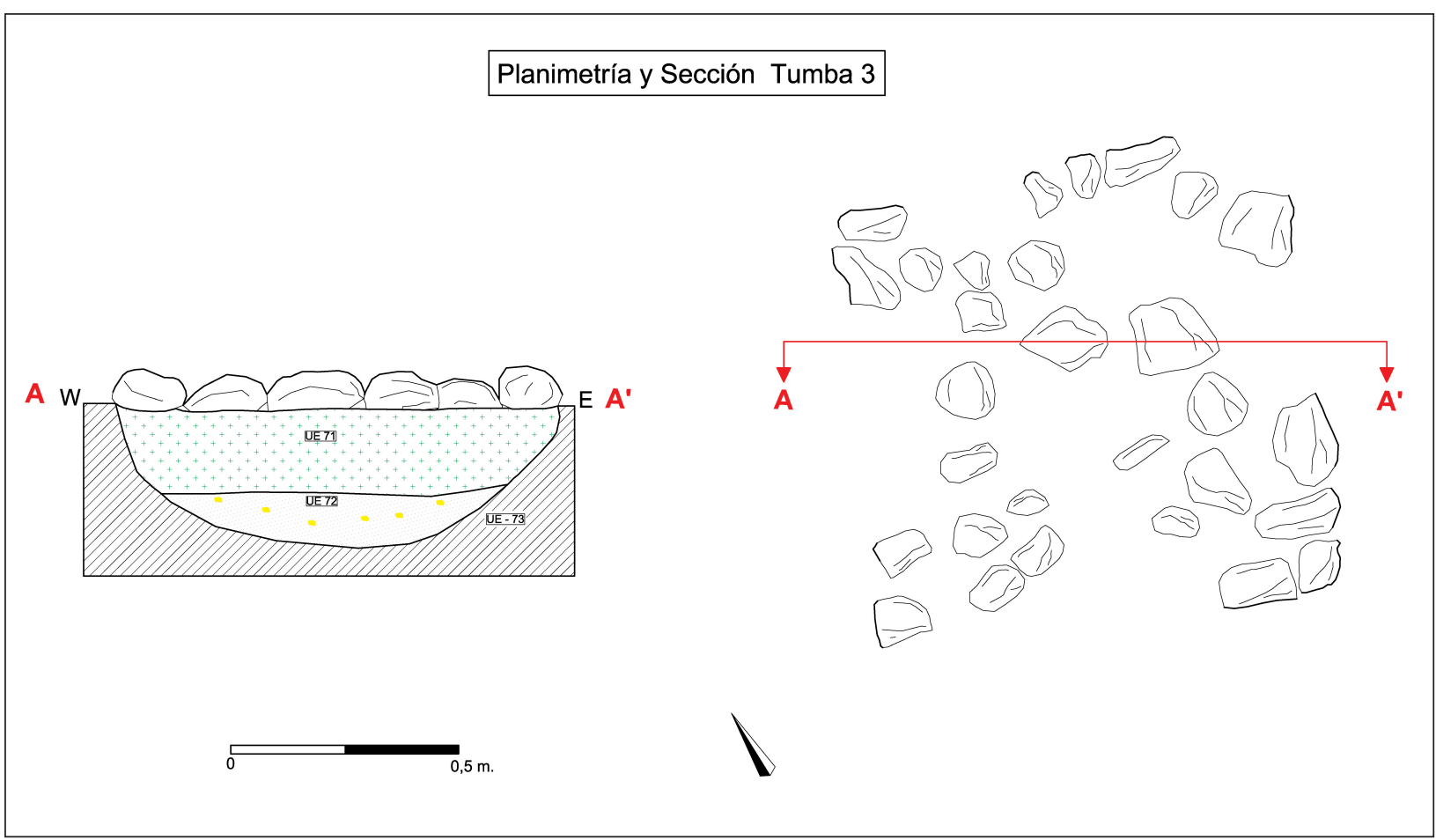

Figura 2.- Planta y sección de la Sepultura 3.

El enterramiento se señalizaba mediante encachado tumular (en la terminología de E. Cuadrado, 1987) de mampostería careada de tamaño medio con unas dimensiones de 0,90 x $0,78 \mathrm{~m}$., orientado en relación a los puntos cardinales y cuyo lado mayor es el alineado en sentido este-oeste. Conserva una sola hilada de altura, si bien es probable que no fuera mucho más alto. En su lado suroeste, el de menor cota, se localizan dos acumulaciones de piedras sueltas que formarían parte de la estructura funeraria y que se vieron desplazados hacia la parte baja de la ladera en el momento del colapso de la estructura.

Entre su ajuar destaca el casco que analizaremos con mayor detalle. Junto a éste se hallaron dos bocados de caballo articulados de tipo filete (Quesada 2005, 117) de camas curvas (Argente et alii 2000,74), una fíbula anular de bronce y un fragmento de aro de otro ejemplar similar, elementos de dos tijeras de esquilar de dorso recto y dimensiones medias (Jimeno et alii 2004, 279): Junto a ello se documenta también un arete de bronce, una arandela de bronce de morfología rectangular y sección circular, una hebilla de bronce, circular, de puente decorado con acanaladuras y sección redondeada, y otros veintinueve fragmentos de hierro indeterminados, que probablemente pertenezcan a los bocados de caballo (Valero 2012a: 183-200).

Hasta qué punto podamos considerar esta sepultura como 'aristocrática' es materia discutible pero relevante. En un contexto del Ibérico antiguo y Pleno (ss. V-IV a.C.) tanto la estructura como el ajuar son relativamente modestos si comparamos con tumbas como las llamadas 'principescas' del Cigarralejo en Murcia (Cuadrado 1987), o con las tumbas más ricas de las necrópolis murcianas o alicantinas de ese periodo. Sin embargo, en el contexto conquense la tumba es rica, y los arreos de caballo, relativamente comunes en las necrópolis celtibéricas, son extremadamente raros en las ibéricas (Quesada 1998 ) y sobre todo el casco, un elemento extraordinario en toda la Península, permiten en conjunto que podamos clasificar esta sepultura, pese a la modestia numérica de su ajuar y la ausencia de material cerámico importado o de una estructura imponente, como 'aristocrática' aunque no 'principesca'. 


\section{LOS BOCADOS DE CABALLO}

La Sepultura 3 contiene dos bocados de caballo, ambos del tipo de filete con embocadura articulada y camas curvas (Grupo A de Quesada 2005, Tipo 4.2 de Tiermes, Argente, Díaz, Bescós 2000).

\section{Bocado 1 (Figuras 3 y 4).}

Bocado de filete articulado con embocadura eficaz de $10.8 \mathrm{~cm}$. de longitud (de extensión máxima, de borde de cama a borde de cama). La embocadura es de sección circular lisa, sin discos, resaltes o dientes.

El rasgo más característico es que se las dos camas son piezas algo diferentes, aunque no tanto como para suponer algo más que una forja poco competente. La primera cama (Fig. 3) presenta placa rectangular plana para el enganche de la embocadura, y no es claro que tenga un orificio adicional menor, necesario para sujetar la quijera de la cabezada, Los brazos de la cama se doblan en ángulo marcado y tienen sección casi cuadrangular. En cambio, la segunda cama tiene una placa plana de diferente forma y tamaño, y los brazos son más curvados, menos angulosos, además de considerablemente más largos.

La apertura máxima de las camas es difícil de precisar, porque los dos extremos están rotos, pero oscilaría en torno a los 14 $\mathrm{cm}$. La segunda cama conserva parte de la anilla móvil a la que se sujetarían las riendas. La longitud total del bocado extendido, de extremo de cama a extremo de cama debió ser de unos $26 \mathrm{~cm}$.

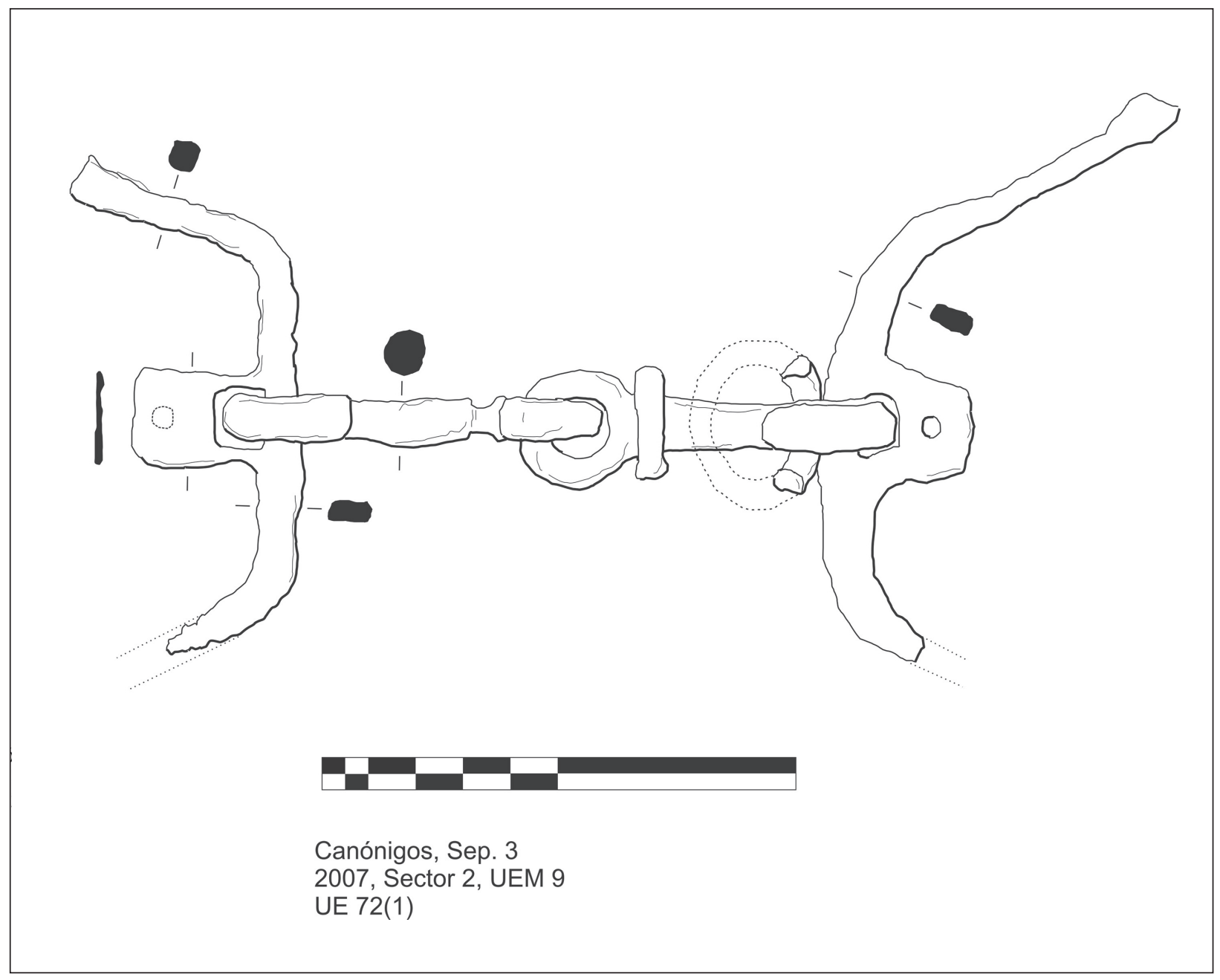

Figura 3.- Bocado de caballo num. 1 de la Sep. 3. Canónigos 2007, Sector II. UEM 9-UE 72(1) 


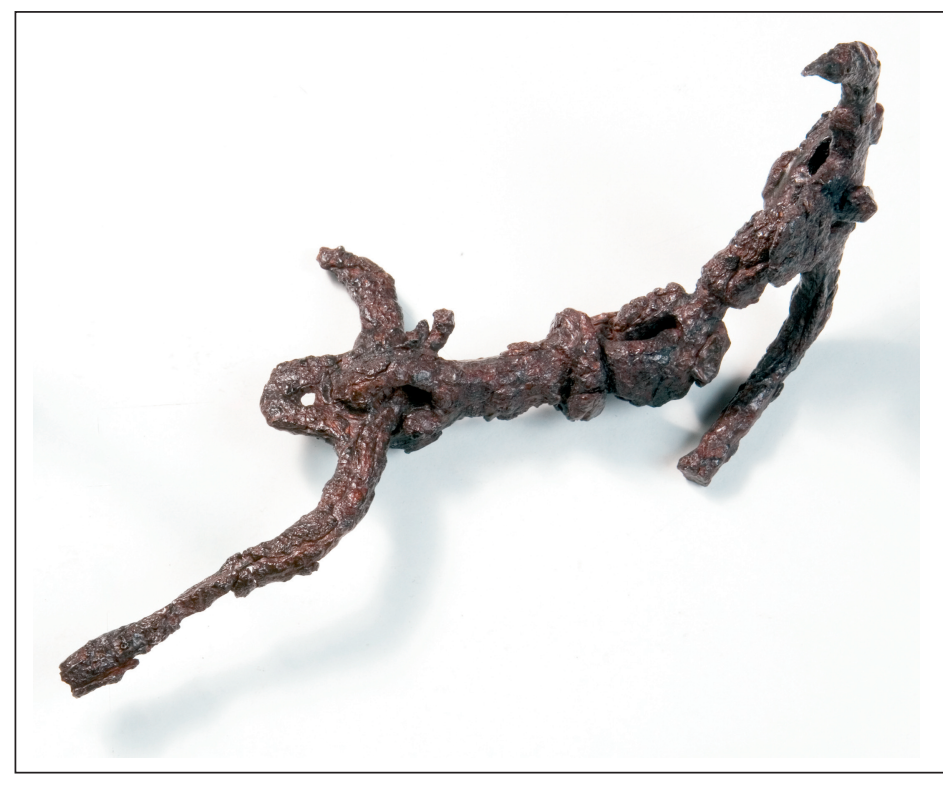

Figura 4.- Foto del bocado de caballo num. 1.

\section{Bocado 2 (Figuras 5 y 6).}

El segundo bocado de la Sep. 3 pertenece al mismo tipo, pero en este caso las dos camas son claramente diferentes en su estructura y fabricación, aunque no en su trabajo, lo que hace al bocado plenamente funcional aunque sin duda fue reparado y una de sus camas sustituida de antiguo, a no ser que se forjara con piezas disimétricas. No es un caso único ni mucho menos, y recientemente se han comentado casos similares por ejemplo en Arcóbriga (Lorrio, Sánchez 2009:358). Una de las camas curvas consiste básicamente en una barra forjada de sección más o menos circular, que en su centro se abre y pliega para dejar dos huecos, uno para la anilla de enganche con la embocadura y a la anilla móvil de las riendas, y otro para la anilla de sujeción de la carrillera o montante. En cambio, la segunda, de dimensiones y forma similares a grandes rasgos, es de placa plana (como en el otro bocado), contando con los mismos elementos funcionales.

A diferencia del primer bocado, la embocadura articulada de este ejemplar cuenta con series de discos para entretener la boca del animal y evitar que trate de morder el bocado, al tiempo que ejercer una mayor acción de control cuando se requiera una respuesta instantánea a la acción de gobierno, aún a costa de causar sufrimiento a la montura.

Las dimensiones funcionales de este bocado son muy similares a las del primero: longitud funcional de embocadura, $10 \mathrm{~cm}$. apertura máxima de las camas, $15,5 \mathrm{~cm}$.; longitud total del bocado, extendido, $24,5 \mathrm{~cm}$.

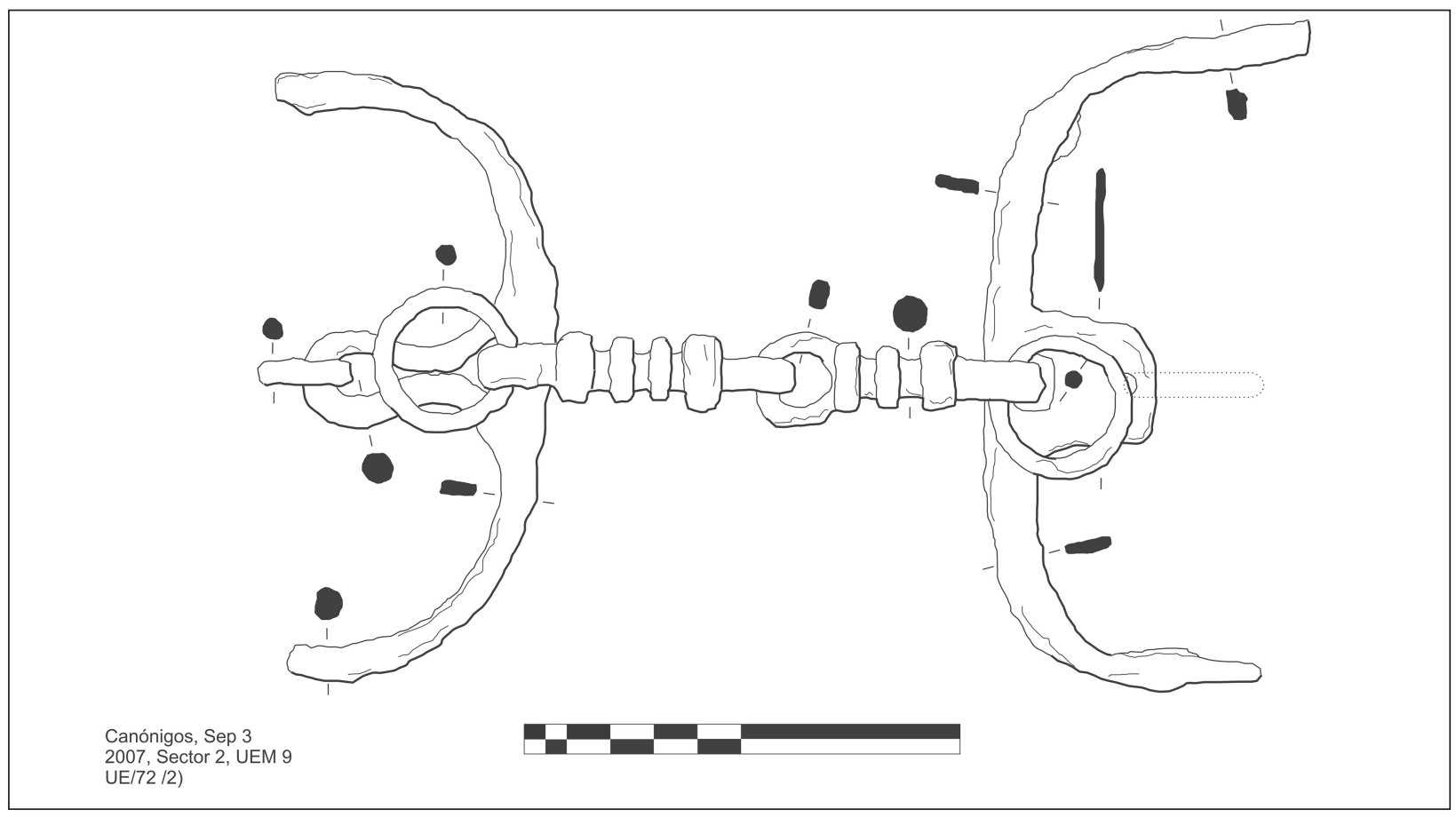

Figura 5.- Bocado de caballo núm. 2. 


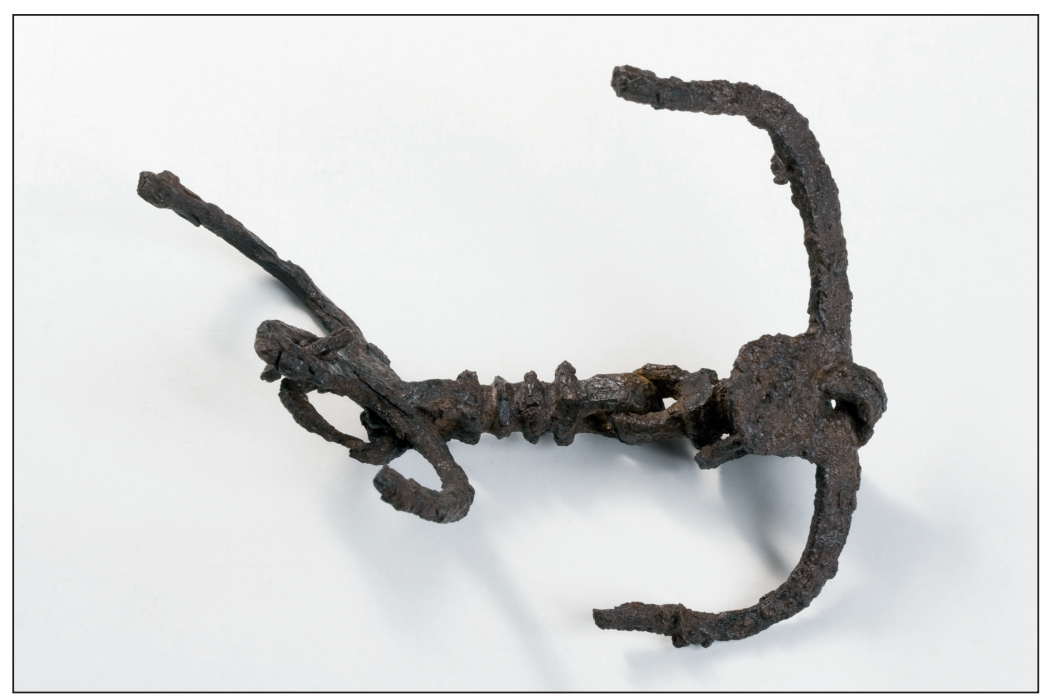

Figura 6.- Bocado de caballo núm. 2

La variante de bocado con cama curva de espacio central porta-anillas en forma de placa plana más o menos rectangular es sólo relativamente frecuente en la Meseta oriental y occidental (menos de una decena de ejemplares), con cronologías de los ss. IV y III a.C. al menos, y quizá desde algo antes como en la Sep. 30 de Sigüenza (Cerdeño, Pérez, 1993: 31 ss.), o en Altillo de Cerropozo (Seps. 15 y 16, final de la Fase II A de Lorrio); Atance (Paz Escribano 1980:Fig. 6; Sep. 31 según la reclasificación de Barril, 2012:Fig. 2.6); Arcóbriga (Lorrio y Sánchez, 2009:273, n. 72) y también en la Sep. 1 de La Mercadera (Taracena 1932:Lám 1) o en Gormaz (Sep. Z de Lorrio 2005, Schüle 1969:Taf. 46.4).

Uno de los paralelos más próximos, tipológica y geográficamente, al nuestro bocado núm. 1 procede de la necrópolis de Buenache de Alarcón (Cuenca) (Losada 1966:Fig. 23), uno de los raros casos de arreos de caballo procedentes de la región conquense. Procede en concreto de la Sep. 10, con una combinación de fíbulas de pie vuelto y anulares, fusayola y urna, que puede fecharse en el s. IV a.C.

Distintas variantes de esta forma, más alejadas de la de Canónigos, se dan también en Almedinilla (Córdoba) (Schüle 1969:Lám. 80.2), Alcácer do Sal (Schüle 1969:Lám. 105.6); La Bastida de Mogente (Dpto. 100) en contextos cronológicos similares de avanzado el s. IV a.C.
La variante de cama con barra subcircular con espacio central porta-anillas plegada sobre sí misma en forma de 'ocho', aparece en la Meseta desde fechas muy antiguas, que cabría llevar hasta el s. V a.C. como quizá en la Sep. 6 de Prados Redondos (Sigüenza) (Cerdeño, Pérez 1993:28) pero que más probablemente pertenecen al s. IV a.C. (como en varias sepulturas de Aguilar de Anguita, por ejemplo en la Sep. D, de la Fase IIA Lorrio). Se conocen sin embargo piezas de cronología más avanzada, como por ejemplo en la Sep. 12 de Altillo de Cerropozo (Cabré 1929 Lám XIV; Schüle 1969:Lám. 16.6) en un contexto de la primera mitad del s. III a.C. por su espada de tipo VI y jabalinas sin nervio (para Lorrio, en su fase IIA2, se fecharía algo antes, en la segunda mitad del s. IV a.C.).

El tipo, sin embargo, se documenta también en fechas muy antiguas en Andalucía, caso de la Sep. 11 de Galera (en último lugar, Pereira et al. 2004:85) del s. V a.C., aunque lo esquemático del dibujo de Cabré y Motos permitiría suponer también un tipo de placa plana.

El tipo genérico de bocado de filete con camas curvas en diferentes variantes es extremadamente común en la Península Ibérica, tanto en el ámbito ibérico como el mundo celtibérico o meseteño en general, y con una amplia cronología ya desde comienzos de la Segunda Edad del Hierro y hasta la romanización, por lo que su empleo para dataciones precisas es complicado y en nuestra opinión inapropiado dada la larga perduración de estos tipos, que alcanzaron una funcionalidad adecuada en fecha temprana y se mantuvieron casi inalterados durante siglos.

\section{LAS FÍBULAS}

En la Sep. 3 de los Canónigos han aparecido dos fíbulas, ambas de tipo anular hispánico. Una de ellas está completa, mientras que de la otra se conserva solo parte del anillo de bronce. 


\section{Fíbula 1 (Figuras 7, 8, 9)}

Fíbula en bronce, de tipo anular. El diámetro del anillo, sólo muy ligeramente deformado, es de 4,2 cm. El puente de navecilla es independiente del anillo, y el resorte es de muelle del tipo II de Cuadrado (Cuadrado 1957:Fig. 2 y p. 9). Resulta imposible clasificarla en alguno de los complejos tipos definidos por Cuadrado (1957 y otros trabajos posteriores), más allá de que pertenece a su tipo 4 (navecilla), pero los terminales y otros detalles no encuentran fácil encaje; por su anillo podría ser un tipo $4 \mathrm{f}$, o un $4 \mathrm{c}$ si consideramos el puente como una variante de terminales foliáceos.... la discusión sería interminable. Desde el punto de vista tecnológico, es una fíbula semifundida, en la que el puente fundida recibe el anillo; encaja pues dentro del tipo 6C de Argente (1994:68), con una amplia cronología desde el s. IV a mediados del s. III a.C. Esta tendencia de clasificación a partir de la técnica es la que en fechas recientes viene teniendo mayor aceptación (e.g. González Zamora 1999), pero de nuevo nuestra fíbula, que formaría parte de la Serie II de dicho autor, no encuentra fácil encaje en los detalles.

Se trata pues de una variante de fíbula muy poco frecuente, por varias razones. En primer lugar, la forma del puente, de sección maciza algo menos que semicircular, formado por una navecilla con un cuerpo central decorado con pequeñas incisiones rectas, enmarcado a ambos lados por dos cuerpos moldurados menores abullonados, que a su vez se prolongan en dos cuerpos alargados de ancho decreciente a modo de montante que enganchan con el anillo.

El aro o anillo, de bronce de sección circular con un grosor homogéneo de unos $3 \mathrm{~mm}$. está decorado con seis grupos (molduras) de cinco líneas incisas profundas con sección en ' $v$ ' que sólo abarcan la mitad superior del ani1lo. Estas molduras, más o menos equidistantes entre sí, delimitan ocho tramos lisos. El conjunto del anillo toma pues un elegante aspecto de molduras estriadas alternando con espacios lisos pulidos.

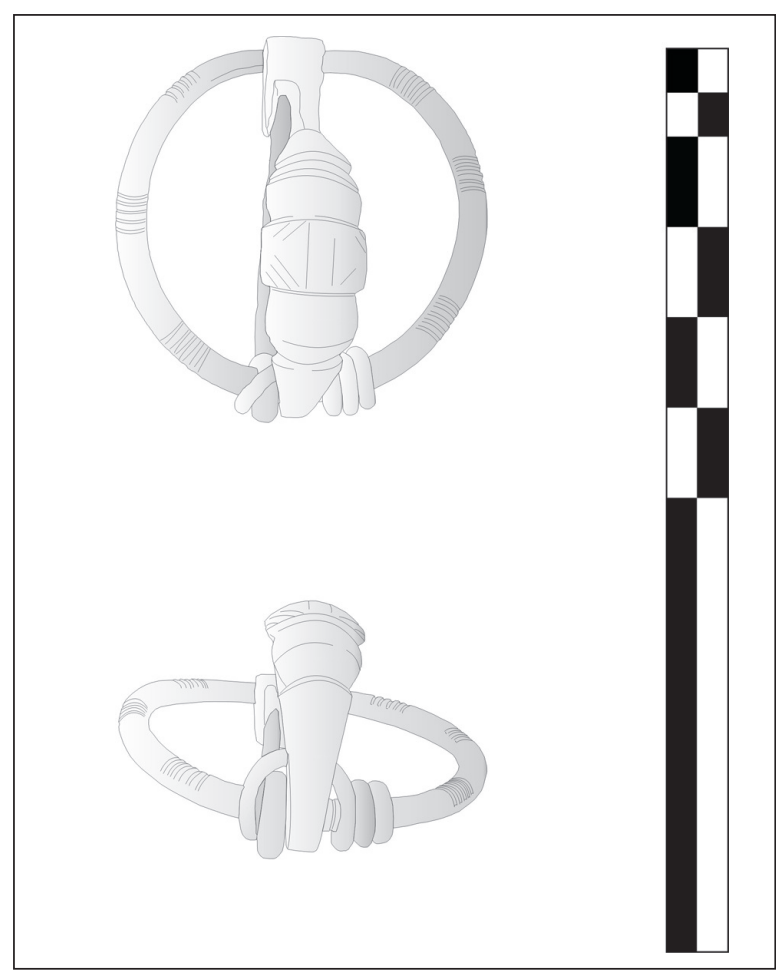

Figura 7.- Fíbula anular hispánica en bronce (dibujo)

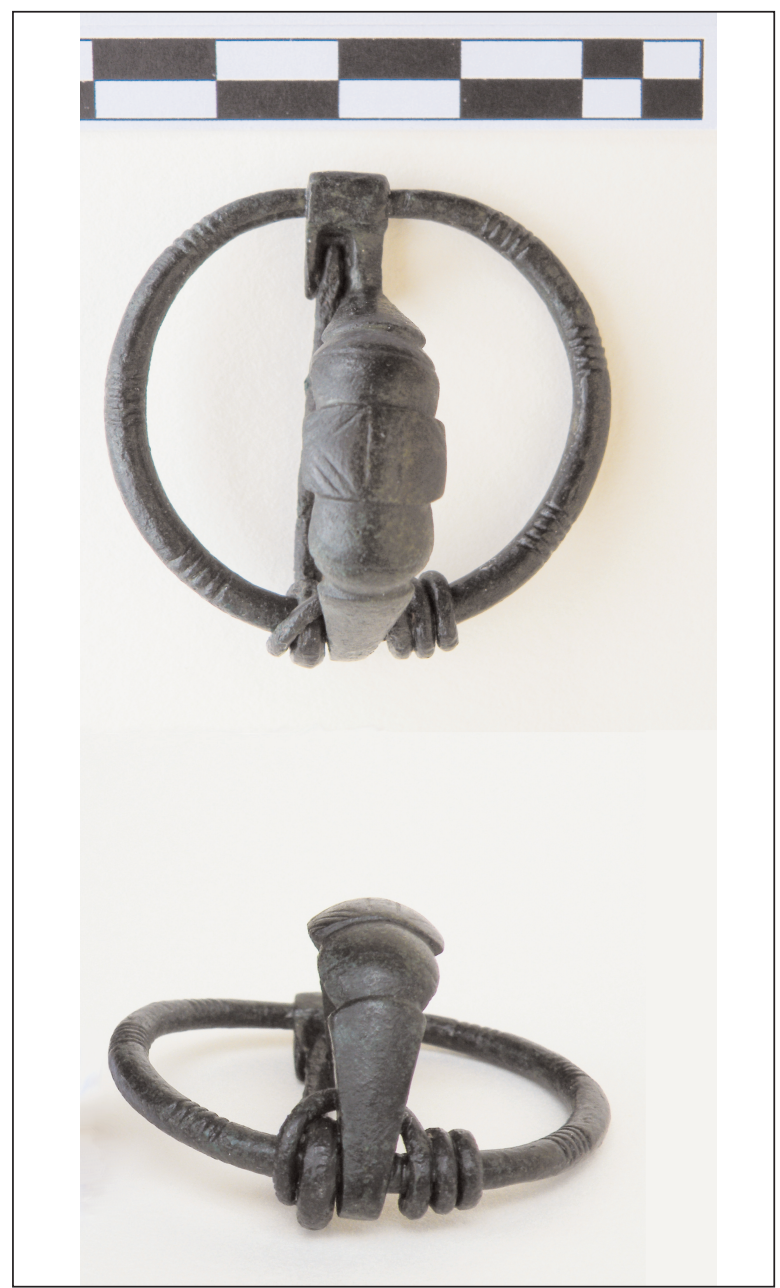

Figura 8.- Fíbula anular hispánica en bronce (foto) 

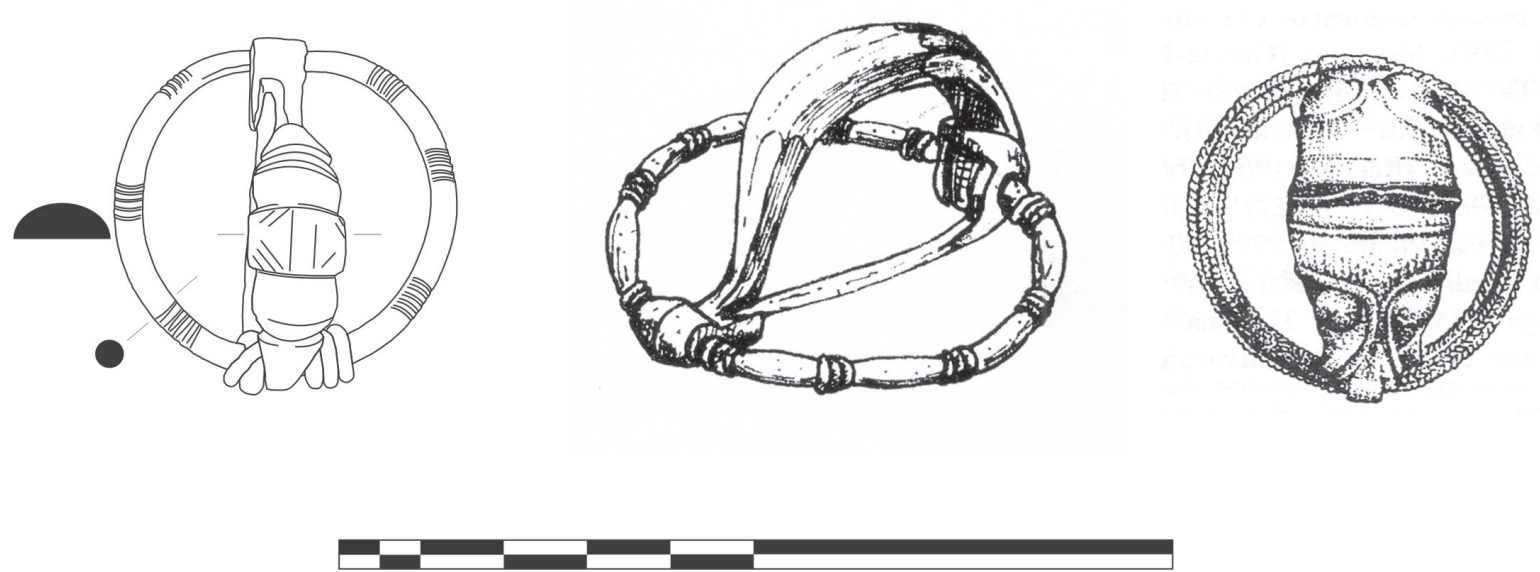

Figura 9.- Izquierda: fíbula de Canónigos. Centro: Fíbula de Olmedilla (según Almagro Gorbea 176-78 Fig. 25.10) Derecha: Fíbula áurtea de Chestae (según Lenerz de Wilde 1991:Abb. 117).

La aguja, que se conserva, se une al anillo por un resorte de muelle de tipo II, un alambre de más de $1 \mathrm{~mm}$. de grosor, que, siguiendo el criterio descriptivo de Cuadrado, viene desde la punta de la aguja, pasa por debajo del anillo a la izquierda de éste, da una segunda vuelta al anillo, pasa al otro lado de la base del puente por el interior de la fíbula y allí da tres vueltas.

\section{Fíbula 2 (Figura 10)}

De una segunda fíbula anular se conserva sólo parte de un anillo algo deformado y algo mayor, de quizá unos $5 \mathrm{~cm}$. de diámetro. Su aspecto es idéntico a la del anillo de la fíbula anterior, aunque los bloques con molduras estriadas se consiguen con cuatro en lugar de cinco incisiones. El grosor del anillo varía entre 2 y $3,5 \mathrm{~mm}$.

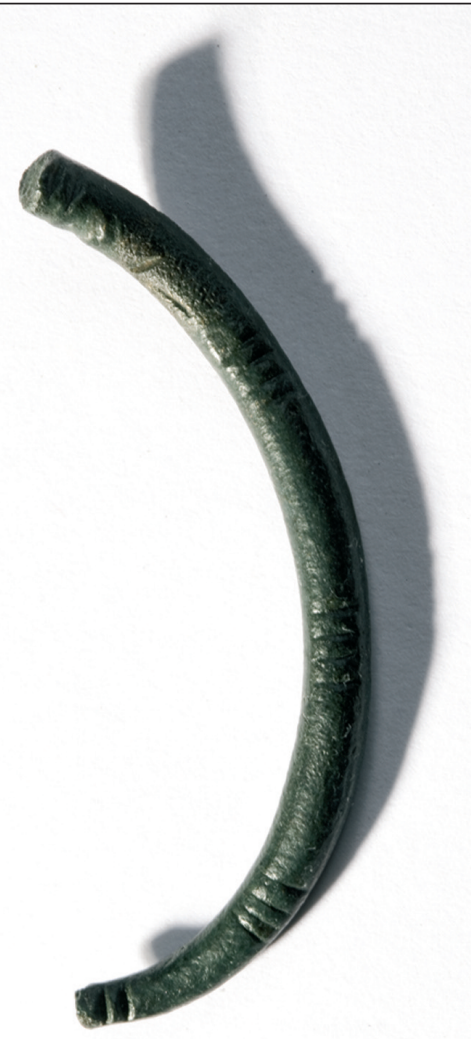

Figura 10.- Fragmento de otra FAH (foto y dibujo). 
Aunque en alguna fotografía de la tumba con materiales fragmentarios (Fig. 19 izquierda) aparece un gran alfiler con resorte de charnela (Long. 6,5 cm.), sin número de inventario, la pátina verde claro es por completo diferente a la del anillo, muy oscura, y además el alfiler parece muy grande para el anillo. Por tanto, si pertenece el fragmento a la Sep. 3, debía ser de una posible y casi por completo perdida tercera fíbula anular.

Este tipo de fíbula anular con navecilla fuertemente moldurada y anillo decorado es casi desconocido en el conjunto de sus detalles combinados. Sólo hemos podido ver, muy cercanos formalmente, un ejemplar expuesto en el Museo de Cuenca procedente de la necrópolis de Carboneras -y hasta lo que sabemos, inédito-, y recientemente se ha publicado preliminarmente una foto sin comentarios de otra, en apariencia casi idéntica, procedente de El Molón, ya en Valencia pero lindando con Cuenca (Lorrio, Almagro, Sánchez, 2009:29).

A nuestro juicio, el tipo de Canónigos puede ser considerado como una variante de fíbula anular con puente de navecilla característico de la zona intermedia entre el ámbito ibérico (área nuclear de este tipo de piezas de tan amplia dispersión) y el celtibérico. Así, en Buenache de Alarcón no aparecen fíbulas próximas a este tipo pese a la abundancia de anulares, y en la próxima y mal conocida necrópolis de Olmedilla de Alarcón se ha publicado piezas cuyos anillos presentan una decoración similar, aunque el resorte es siempre, en lo que se puede apreciar, de charnela (Almagro Gorbea, 1976-78). Almagro relacionaba ya Olmedilla y Buenache con el ámbito ibérico del Sureste y de Levante, y fechaba el conjunto de Olmedilla entre los ss. IV y III a.C. El catálogo de las cerámicas de esa región realizado por Pilar Mena no desmiente esa aproximación aunque ciertamente hay urnas de orejetas y otros elementos en Olmedilla que indican mayor antigüedad que el s. III a.C. (Mena 1984:70) y otras que perfectamente podrían llevarse hasta avanzado el s. III a.C. (Mena 1984:81).
Los anillos con decoración incisa formando molduras no son habituales, pero los ejemplares que conocemos fuera del entorno conquense inmediato viran hacia el este, hacia el ámbito ibérico, caso de la fíbula anular n. 10 del Dpto. IV de La Bastida (Valencia), fechable a fines del s. IV a.C., o el del Dpto. 36.1, aunque en este caso la estructura del resorte de charnela, es diferente, y el puente es mucho más sencillo. En la zona inmediata al sur y al este apareen algunas fíbulas con anillos decorados con incisiones, aunque con puentes de navecilla o timbal muy distintos, caso de las necrópolis de Pozo Moro (Sanz, López, Soria 1992: Figs. 5.11.39); Camino de la Cruz (Sanz, López, Soria 1992:Fig. 5.8.23 o Casa del Monte (Cisneros 1992:201 y Fig. 2.1; Sanz, López, Soria 1992: 9; Fig. 5.26, n. 130). Más hacia el sur/sureste, hacia la región murciana, estos anillos decorados no parecen darse (Iniesta 1983).

Cabría incluso pensar en la relación posible con piezas mucho más elaboradas en metales preciosos, como la fíbula de oro del tesoro de Cheste (Valencia), la de Turis (Valencia) (Rams 1975 Láms. III y IV) o una de las de Driebes (Guadalajara), modelos a partir de los que la pieza de Canónigos podría ser una versión extremadamente estilizada y simplificada hasta perder el carácter antropomorfo de los prototipos. Aunque se ha insistido en que los tesoros de la zona conquense tienen un aire celtibérico limítrofe (Lorrio 2005:200 ss.), dada la presencia de decoraciones de cabezas humanas enlazadas por la coronilla en piezas claramente ibéricas del s. IV a.C., fundamentalmente empuñaduras de falcatas (Quesada et alii. 2000), la conexión ibérica no puede desestimarse en absoluto, antes al contrario. Lorrio (2005:202) ha considerado también como propio de estímulos ibéricos los anillos de fíbulas decorados con 'contarios', quizá vinculados tipológicamente con nuestros ejemplares como también los casos que ya recogiera Cuadrado (1957:Figs. 21, 22; 1957b: Figs. 7-8; 1960) de diversas procedencias, incluyendo la Meseta.

Pero también cabría, por otro lado, vincularlas con los anillos de FAH sogueados, como en el caso de la fíbula anular hispánica en plata del Santuario de la Encarnación en 
Murcia, sin datación precisa más allá del margen s. IV-II a.C. (Brotons, Ramallo, 2010:167 y Fig.17.91)... pero también con la fíbula anular lobuna de Armuña de Tajuña (Guadalajara) (González Zamora, 1999: Lám. V).

En estos casos nos moveríamos probablemente en un entorno del s. III a.C. antes que en el IV, aunque la fecha más antigua no es imposible. La idea de Daugas y Tixier (recogida por Martín Montes (1984:39) de que las fibulas con puente fundido de navecilla son del s. III es una esquematización que, siguiendo a Argente (1994:7) debemos permitir remontar, incluso ampliamente, hasta el s. IV a.C. Pero del mismo modo, y a la inversa, la presencia de una fíbula de muelle no es un indicio cronológico decisivo que apunte mayor antigüedad; algunas de las fíbulas más tardías adoptan este resorte (Argente 1994:68-69). Desde el punto de vista cultural, los mejores paralelos se encuentran hacia el esta, hacia el territorio ibérico, y no hacia el oeste o el norte, el ámbito meseteño, donde no parece que se den los elementos de detalle decorativo que venimos mencionando.

\section{LAS TIJERAS}

En Canónigos aparecen dos grandes tijeras del modelo tradicionalmente asociado a la esquila de ganado lanar (Pla 1968:159; Chapa, Mayoral, 2007:74 ss.). Se trata de un tipo sencillo creado a partir de una sola pieza de hierro forjado y doblado formando un puente flexible, con dos hojas triangulares alargadas que se unen por presión de la mano, y se separan al cesar la misma. Su tamaño oscila mucho, entre los 10 y los $30 \mathrm{~cm}$. de longitud. Las menores de $17 \mathrm{~cm}$. serían de uso doméstico, las mayores, que pueden llegar a los $70 \mathrm{~cm}$., no deben probablemente asociarse al esquileo sino a otros trabajos (Alfaro 1978).

\section{Tijeras 1 (Figuras 11-12)}

La primera tijera está prácticamente completa aunque partida por el puente, su punto más débil -y el de mayor tensión durante el uso-. Se trata de una pieza grande, en el rango alto de las conocidas, con $26 \mathrm{~cm}$. de longitud máxima. Las hojas son robustas, con un filo de $14 \mathrm{~cm}$. útiles y un dorso grueso de $0,5 \mathrm{~cm}$. de grosor, casi como una espada, lo que da indicio de su robustez. Del mismo modo, los brazos hacia el arco o puente, que permiten hacer palanca, son muy robustos, de sección rectangular y hasta $1 \mathrm{~cm}$. de ancho en el lado mayor.

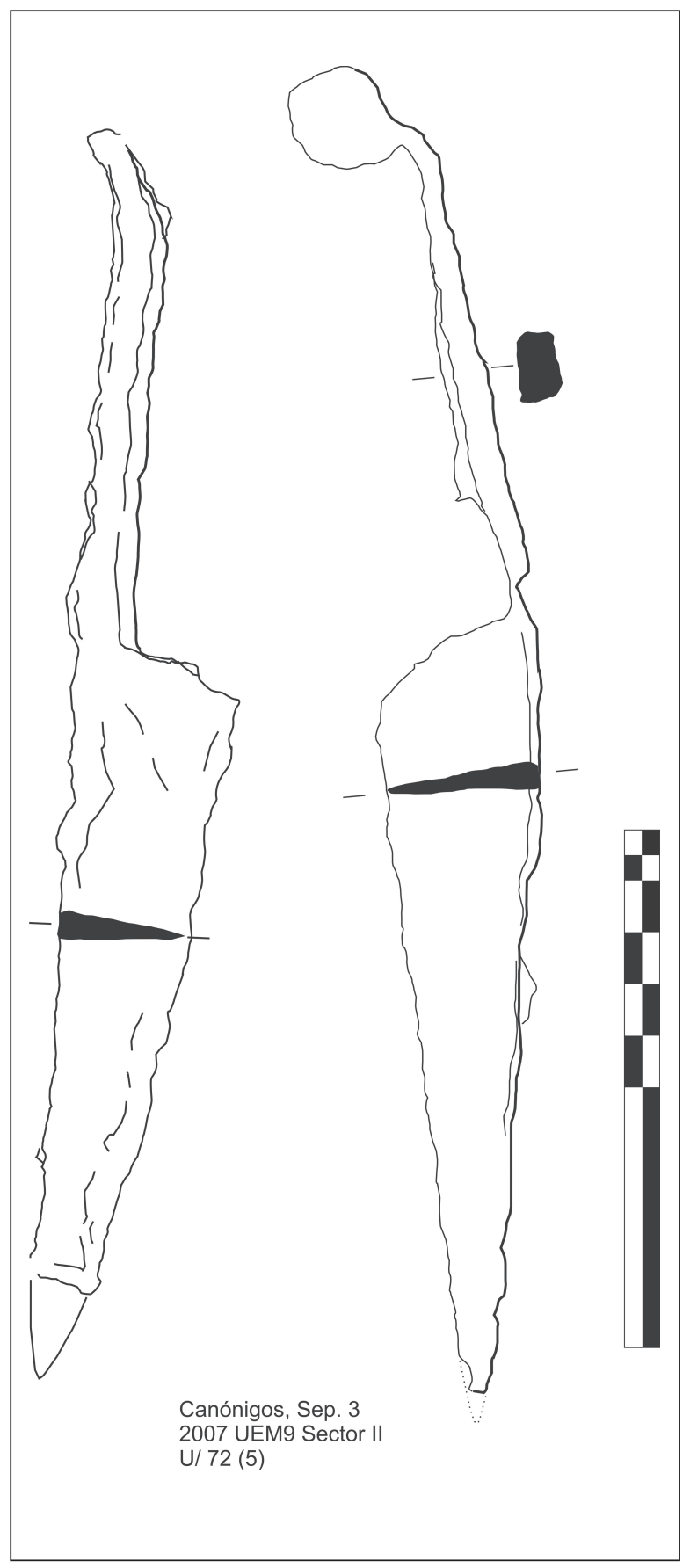

Figura 11.- Tijera 1 


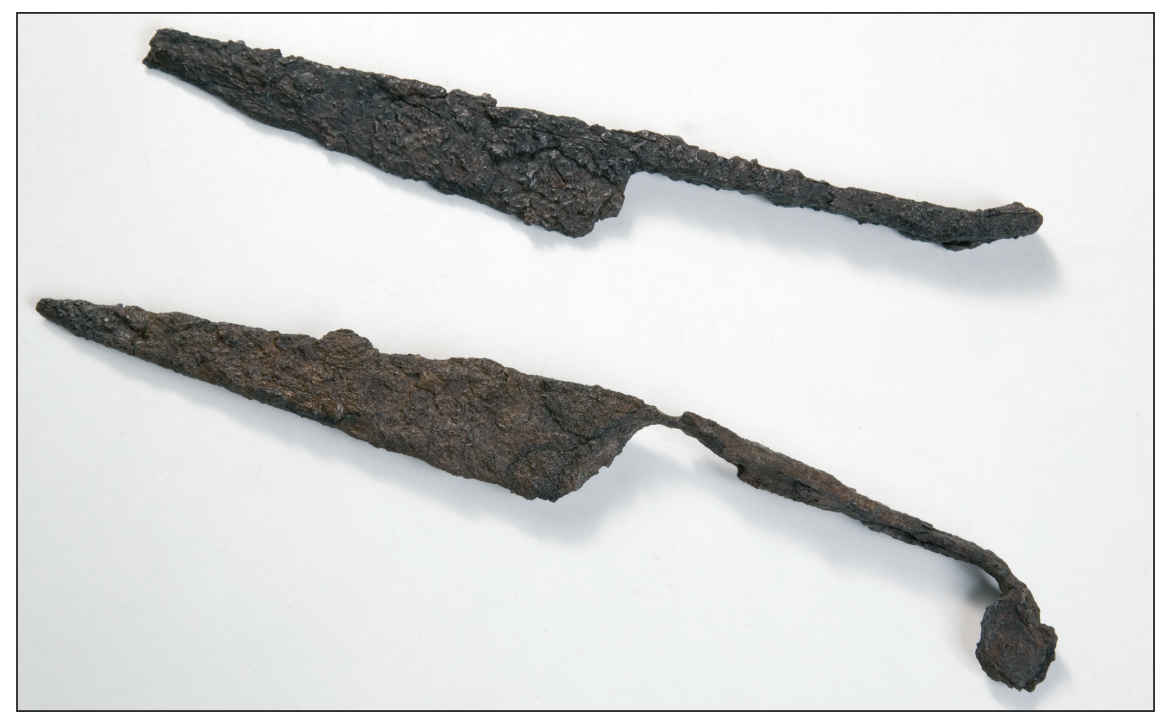

Figura 12.- Tijera 1

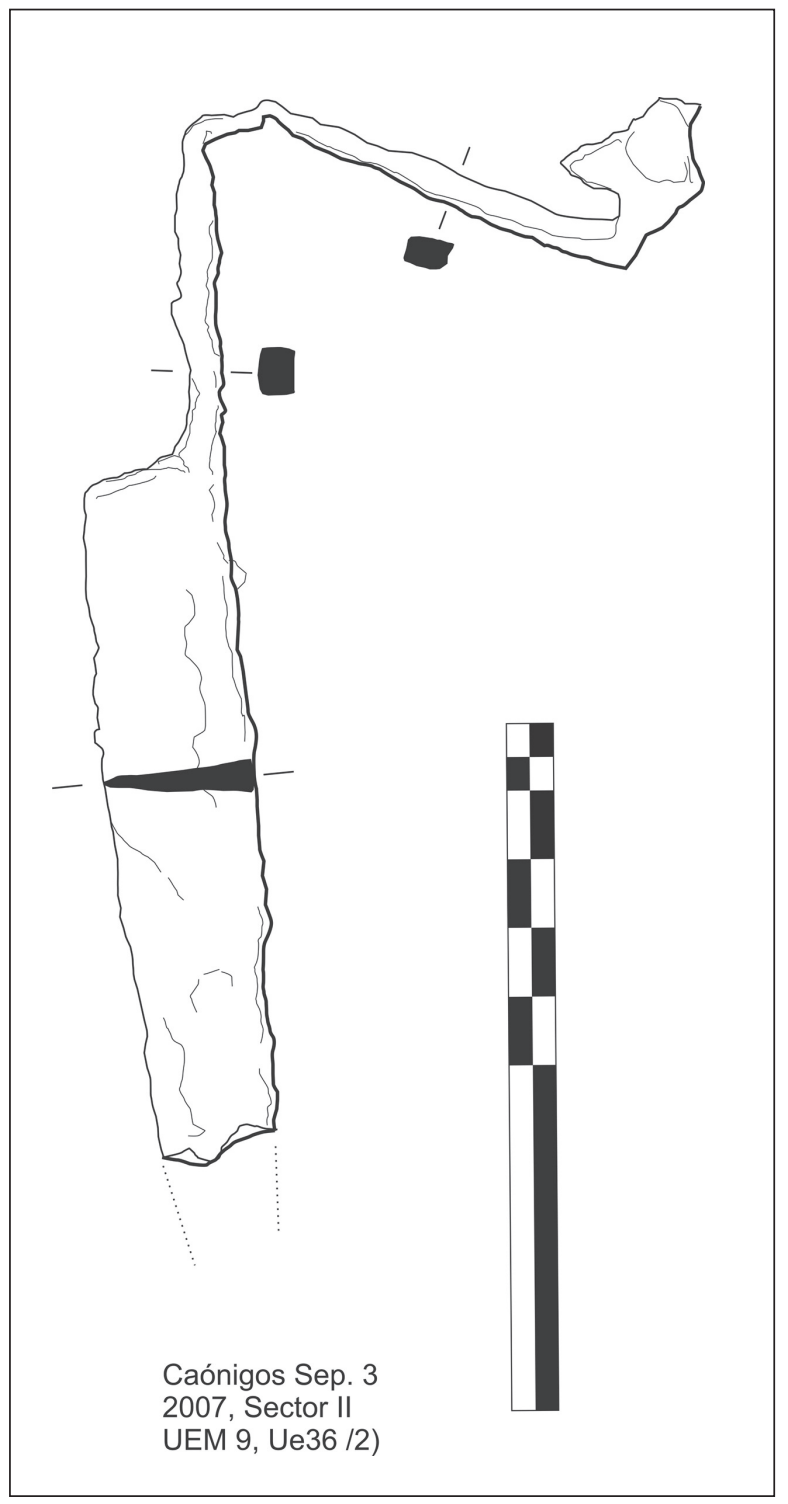

Figura 13.- Tijera 2

\section{Tijeras 2 (Figuras 13-14)}

De la segunda tijera sólo se conserva una de las mitades y el puente, doblado en ángulo recto y en una posición tan forzada que parece claro que resulta de una inutilización intencionada. La hoja, triangular alargada como en el caso anterior, está incompleta, pero debió medir unos $14 \mathrm{~cm}$. de filo, casi como la pieza anterior, aunque no es tan grande o robusta. La sección de la hoja es triangular, con un dorso de unos $0,4 \mathrm{~cm}$. de grosor. Los brazos son, como en el caso anterior, de sección rectangular.

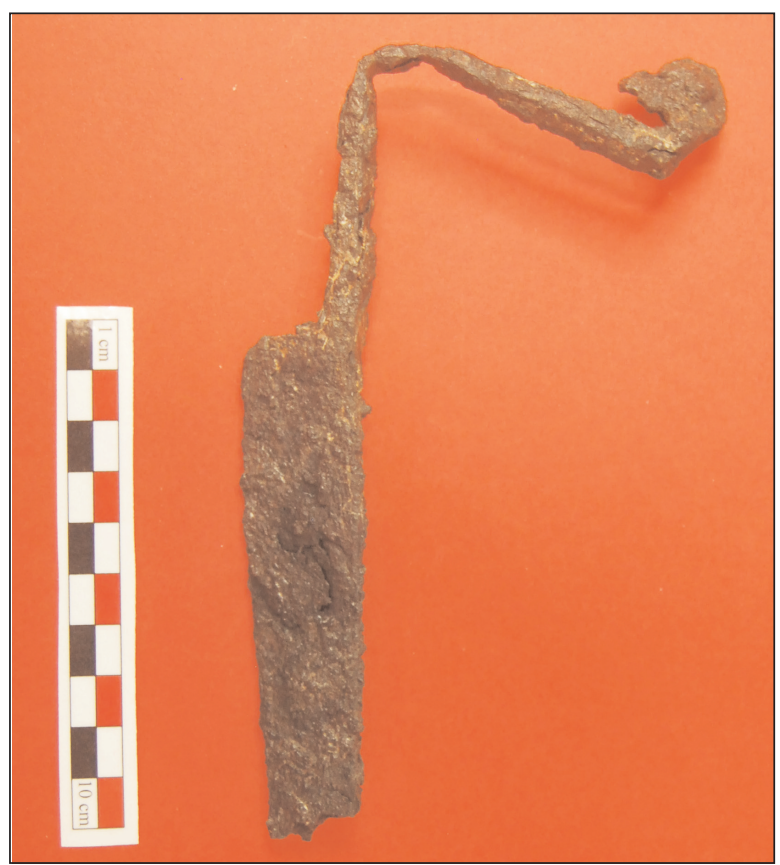

Figura 14.- Tijera 2 
Las tijeras de Canónigos son grandes (longitud máxima en torno a los $26,5 \mathrm{~cm}$.), por tanto están claramente en el grupo de las mayores dentro de las de esquileo, Alfaro 1978). Su tamaño coincide, en efecto, con los mayores de los pocos lugares donde se han hecho estudios estadísticos por contar con un número suficiente de ejemplares, caso de Carratiermes (Argente, Díaz, Bescós 2001:128) o Numancia (Jimeno et al. 2004: y Fig. 202

Las tijeras 'de esquilar' de una pieza son abundantes en poblados ibéricos del Nordeste (Auladell 1993: Fig. 2; Sanahuja 1971:93-94 y Fig. 19, Anseresa, Masnou...); Levante (Kelin, Pérez et al. 2000:156; La Bastida, Covalta., Pla 1968:159; Pérez Jordá et al. 2011); Sureste (Grau, Reig 2002-3:138; La Serreta de Alcoy; $c f$. Moratalla 1994); y en los meseteños occidentales y orientales (e.g. Raso de Candeleda, Fernández 2011:341; Langa de Duero, Barril 1992:18; Numancia, Jimeno et al. 1999:109; cf. también Berzosa 2007); en el norte (Montesclaros, Alfaro, 1978:302) y un largo etc. De hecho, es un tipo extendido fuera de la Península Ibérica, por ejemplo en el sur de Francia (e.g. Chardenon 2000:291; cf. también Alfaro 1978).

Lo significativo es que un utensilio modesto es también habitual en las necrópolis peninsulares -ibéricas y meseteñas- de la Edad del Hierro. Se asocian tanto a tumbas de guerreros como a otras que por su ajuar tenderían a ser consideradas femeninas, como a otras cuyo ajuar no presenta especiales particularidades. Así por ejemplo, en Cigarralejo (Murcia) las tijeras se asocian a armas en las Seps. 79 y 161 (ambas del s, IV a.C.) y no se asocian a armas en la Sep. 110 (fin s. IV-s. III a.C.) (Cuadrado 1987). En la Sep. 7 de El Tesorico de Hellín (Broncano et al. 1985:Fig. 38,171 ) también se asocian a armas (es un tipo peculiar de tijera con una suerte de muelle en el puente).

En el ámbito meseteño, y por citar un ejemplo, en Carratiermes, donde se conocen 34 piezas, las tijeras se asocian a armas en casi la mitad de los casos (Argente, Díaz, Bescós 2001:128. En Numancia, 27 ajuares contienen 31 ejemplares, y de esos 27, 12 contienen además armas (ibidem pp. 279 ss.). Aparecen por fin tijeras en casi todos los yacimientos con amplia excavación como Quintanas de Gormaz, la Mercadera, Osma, (Alfaro 1978:306), Arcóbriga (Lorrio, Sánchez 2009:348 ss.), etc. En la necrópolis de Cabrera de Mar, en la Laietania, parecen tambien asociarse a tumbas con armas (Barberá 1968); en el sureste, se conoce media docena de ejemplares de El Cigarralejo (Cuadrado 1987 y diarios). En conjunto la sensación es que hay más abundancia en las zonas de la Meseta Oriental que en ningún otro lugar, pero puede ser una impresión engañosa.

Por tanto, la asociación de armas e instrumentos agrícolas o ganaderos en una tumba no debe de extrañar teniendo en cuenta la estructura aristocrática de la sociedad ibérica: un noble, en su oppidum o en su granja, era a la vez un guerrero y un agricultor o ganadero, y podía llevar a su tumba elementos alusivos tanto a su ética bélica como a la actividad productiva que le proporcionaba su riqueza y rango, sin que ello suponga contradicción alguna, ya que en las sociedades ibérica o celtibérica no existieron estamentos cerrados de guerreros aislados de la actividad económica. Un buen ejemplo sería, sin duda, el noble rural que controlaba el asentamiento del Castellet de Bernabé en Valencia (Guerin 2003). Más significativo aún es el caso del Dpto. 4 del fortín ibérico del Puntal dels Llops, también en Valencia, en el que, como en nuestra tumba, se asocian fragmentos de unas tijeras de esquilar (n. 4111, Bonet y Mata 2002:3054) con un ronzal de caballo, espuelas y otros elementos de atalaje, además de los elementos normales de la vajilla doméstica de 'gama alta'. Es, en opinión de sus excavadores, el 'recinto más noble del asentamiento' (Bonet, Mata 2002:68).

Como ocurría en el caso de los bocados de caballo, el paralelo cercano más inmediato geográficamente a las tijeras de Canónigos es el de la Sep. 9 de Buenache de Alarcón, tumba que es la más rica de ese yacimiento (Losada 1966:Fig. 19), que cuenta entre otros elementos de ajuar con un broche de cinturón de placa rectangular de tipo ibérico, fusayo- 
las, pinzas de depilar, etc. Pero, insistimos, el tipo es muy común tanto en el ámbito meseteño como en el ibérico y algunas distinciones sobre su mayor presencia por ejemplo en el Alto Duero y menor en el Alto Jalón (Jimeno et al. 2004:280) son quizá, por ahora, demasiado sutiles en el estado actual de nuestros conocimientos.

Por lo que se refiere a la datación, en Carratiermes todas las tijeras halladas en contexto se fechan entre la segunda mitad del s. IV a.C. y el s. II a.C. (Argente, Díaz, Bescós 2001:128), en Numancia en el s. II a.C. (Jimeno et al. 2004); en Bastida en la segunda mitad del s. IV (Pla 1968), en Cigarralejo entre el s. IV y el II a.C. (Cuadrado 1987) etc. De hecho, el tipo de instrumento es tan sencillo y su eficacia tan acreditada que en realidad ha perdurado casi sin modificaciones hasta la actualidad y no tiene potencial alguno como indicador cronológico.

\section{OTROS ELEMENTOS METÁLICOS: HEBILLAS (Figura 15)}

Por razones de espacio no nos detendremos aquí (remitimos a la Memoria de excavación) en una serie de tres elementos de bronce, muy robustos y con señales de desgaste. El primero es una anilla de sección circular, con un diámetro aproximado de 4 $\mathrm{cm}$. y un grosor en sección de 6-8 mm., por las protuberancias que presenta, originales del molde y desgastadas. El segundo es una pieza trapezoidal, con el lado corto curvado. Mide $6,6 \mathrm{~cm}$. de longi- tud máxima, 4,3 cm. en el lado ancho, y el grosor de la barra de bronce, de sección circular, es de $6 \mathrm{~mm}$. Finalmente, la tercera pieza es una masiva hebilla de bronce, circular con un diámetro de $6 \mathrm{~cm}$. y un grosor de casi $7 \mathrm{~mm}$. La aguja, móvil es de sección cuadrada al comienzo, y rectangular en el extremo.

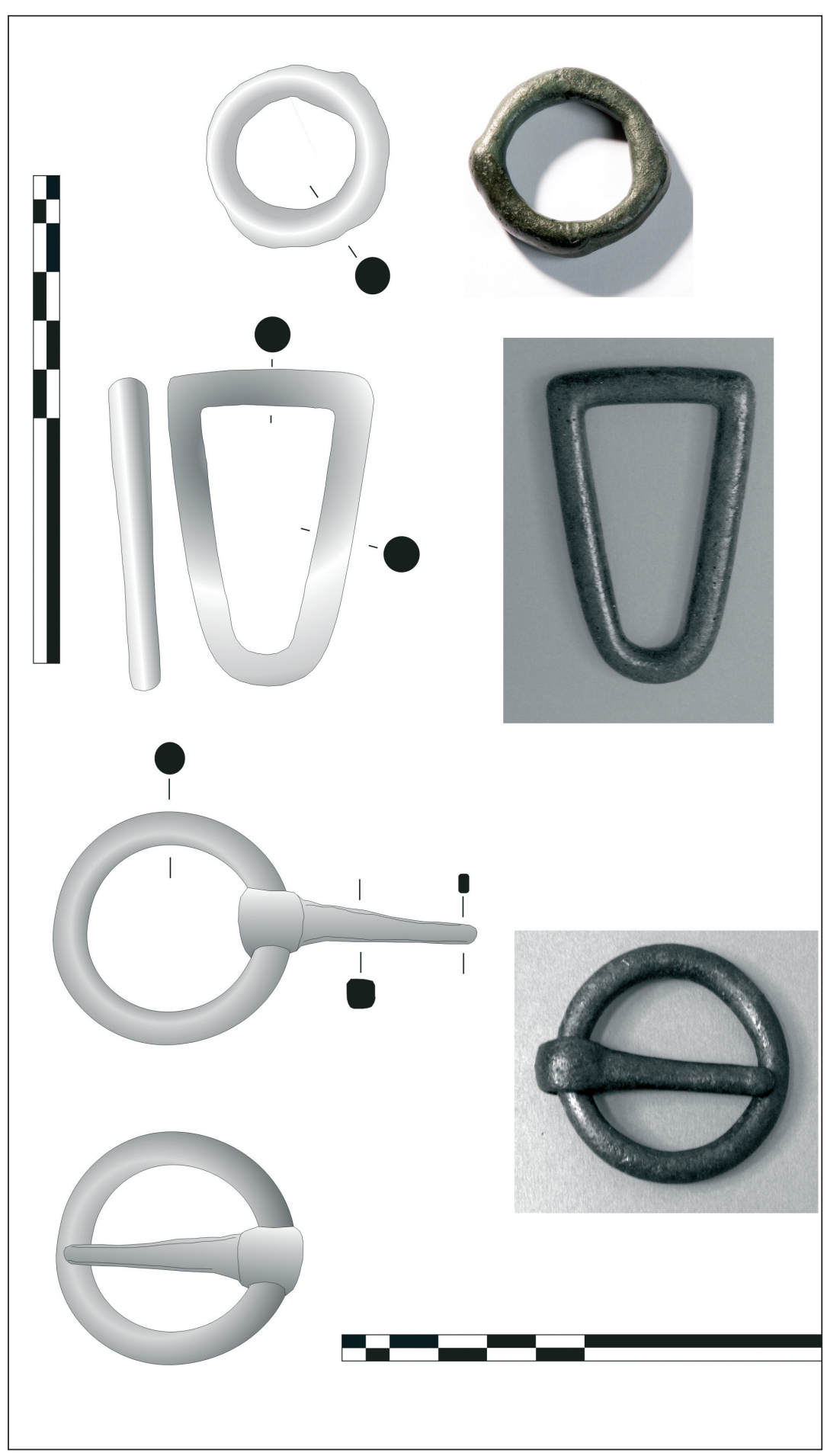

Figura 15.- Hebillas y otros elementos metálicos 
Creemos que se trata de elementos de atalaje de caballo. asociados a las correas de cuero de la cincha de sujeción del ephippion, y en su caso petral y otros elementos. Renunciamos a una búsqueda de paralelos, pero aunque no son piezas habituales, a título exclusivamente de ejemplo mencionaremos que en la Sep. 48 de la necrópolis de Numancia (s. II a.C.) hay una hebilla circular muy similar en tamaño, aunque forjada en hierro, asociada igualmente a elementos de una cabezada de caballo. Hay otros ejemplares, por ejemplo en Sep. 108, 134, etc. (Jimeno et al. 2004). Y en el otro gran ambiente cultural, el ibérico, la hebilla circular de c. 5-6 cm. se encuentra, por ejemplo en la Sep. 200 del Cigarralejo, también asociada a arreos de caballo, y en este caso también en bronce, como en Canónigos (Cuadrado 1987: Fig.146.17)

\section{El casco. (Figuras 16-18 dibujos; 19-27 fotos).}

\section{Conservación. Daños intenciona- dos.}

El elemento más llamativo del ajuar de la Sepultura 3 es un casco de bronce casi completo pero muy fragmentado, aplastado y dañado intencionalmente ya antes de ser depositado en la tumba. Ha sido restaurado por el Instituto del Patrimonio Cultural de España (exp. 23.551; ver Rey 2008; Navarro, 2008; Antelo, 2008) y es posible reconstruir con bastante fidelidad su estructura (Figs. 16-20), que corresponde además con un tipo ya conocido antes en la Península Ibérica y, como veremos, de gran importancia.

En el momento de su aparición, el casco estaba aplastado lateralmente (Figuras 18 y 21). La calota estaba además fragmentada en tres grandes trozos, correspondientes a la zona delantera, trasera y superior, esta última completamente aplastada y plegada sobre sí misma (Figura 19). Sin embargo, faltaba el remate macizo de bronce característico, como enseguida veremos, de este tipo de cascos, pieza sólida y difícil de destruir que, precisamente por esta razón, creemos que no ha aparecido porque posiblemente nunca se introdujo en la tumba.

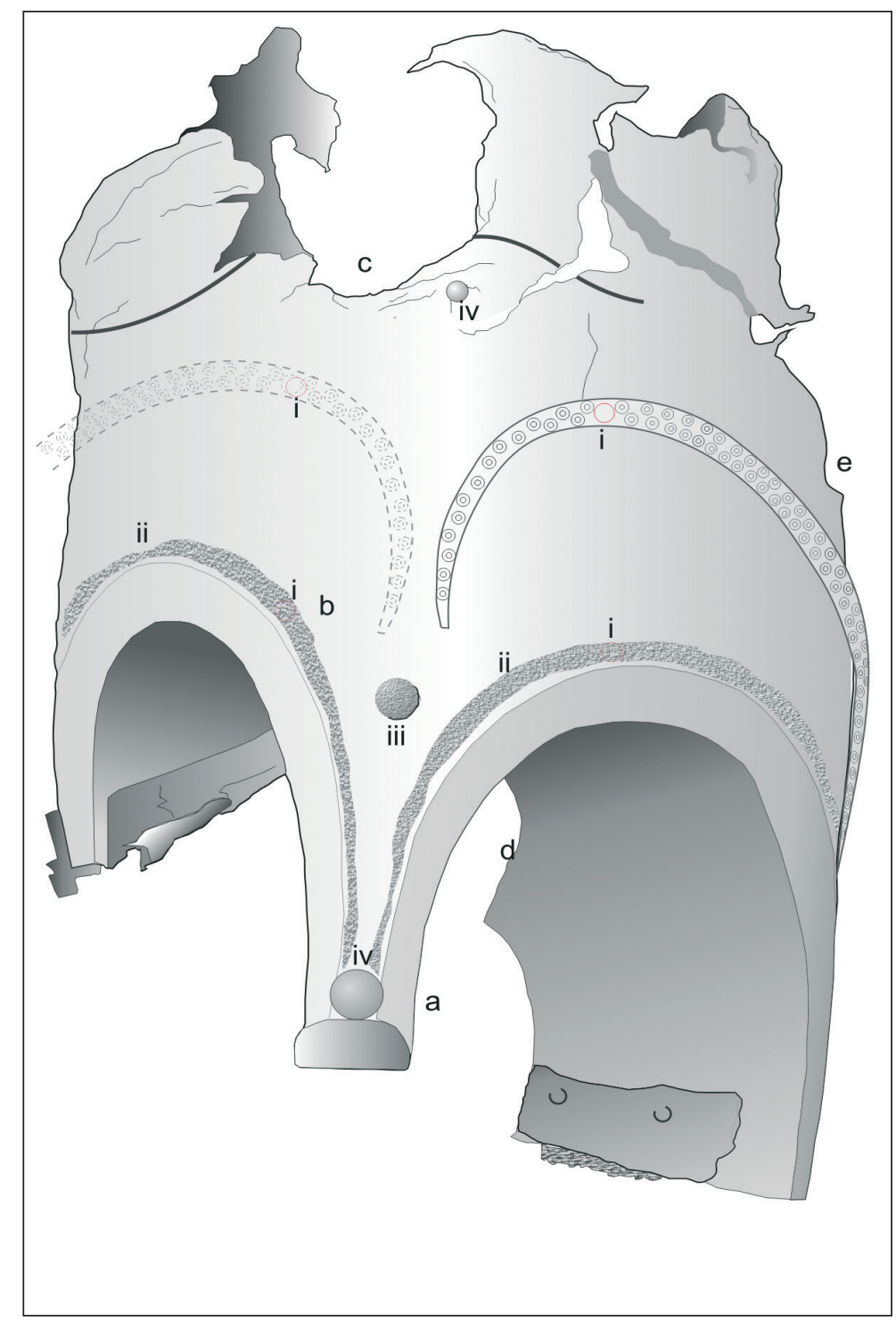

Figura 16.- Casco de Los Canónigos, dibujo frontal. Leyenda de las figuras 16-18): Letras minúsculas: grosor de la chapa en diferentes puntos. (a): 5-6 mm. (b): $3 \mathrm{~mm}$.; (c) $1 \mathrm{~mm}$.; (d) $2 \mathrm{~mm}$.; (e) mm.; (f): $0,6 \mathrm{~mm}$; (g) $0,8 \mathrm{~mm}$.

Números romanos: (i) Orificios para remache de bronce de pequeño diámetro;. (ii) Improntas de óxido de hierro de un aplique en ese metal; (iii) Remache en hierro de cabeza hemiesférica aplanada o su orificio;

(iv) Remache en bronce; (v) Aplique de hierro de refuerzo y decoración (vi) Orificios en carrillera, quizá para sujeción de barboquejo;

(vii) Pletinas para la bisagra de la carrillera; (viii) Perforaciones para sujetar la pletina para sujetar plumas; (ix) Par de perforaciones en el centro del guardanuca (x) Pletina plegada para sujetar plumas al lateral del casco. (xi) Marcas de impacto de golpe. 
Además, la parte superior del casco muestra lo que parecen varios golpes realizados con un instrumento tajante pesado pero no muy perforante, quizá el filo de una espada (Figuras 17 y 18, flechas; Figura 20, indicados mediante flechas).

La inutilización ritual de cascos mediante una combinación de aplastamiento y golpes es extremadamente frecuente en diversos ámbitos ritualizados del Mediterráneo (Gabaldón 2004 passim), desde Fenicia (e.g. Warmenbol 1983) a Grecia (e.g. Jackson 1983), la céltica (e.g. Brunaux, Rapin 1988) y la Edad del Hierro de la Península Ibérica, y es casi una constante en los cascos de tipo Montefortino característicos de los ss. III-II a.C. depositados en tumbas (Quesada 1997:564 y Lám.XIB). El caso más evidente es el de la brutal inutilización con espada del casco romano amortizado en la Sep. 4F/2 de la necrópolis de Pozo Moro (Quesada 1997:Lám XIA, 1997b:156-157; para su epígrafe latino de $\mathrm{Hoz}$ 1994; para el contexto Alcalá Zamora 2003:56 ss.; y la reinterpretación del conjunto en García Jiménez, Quesada 2012).

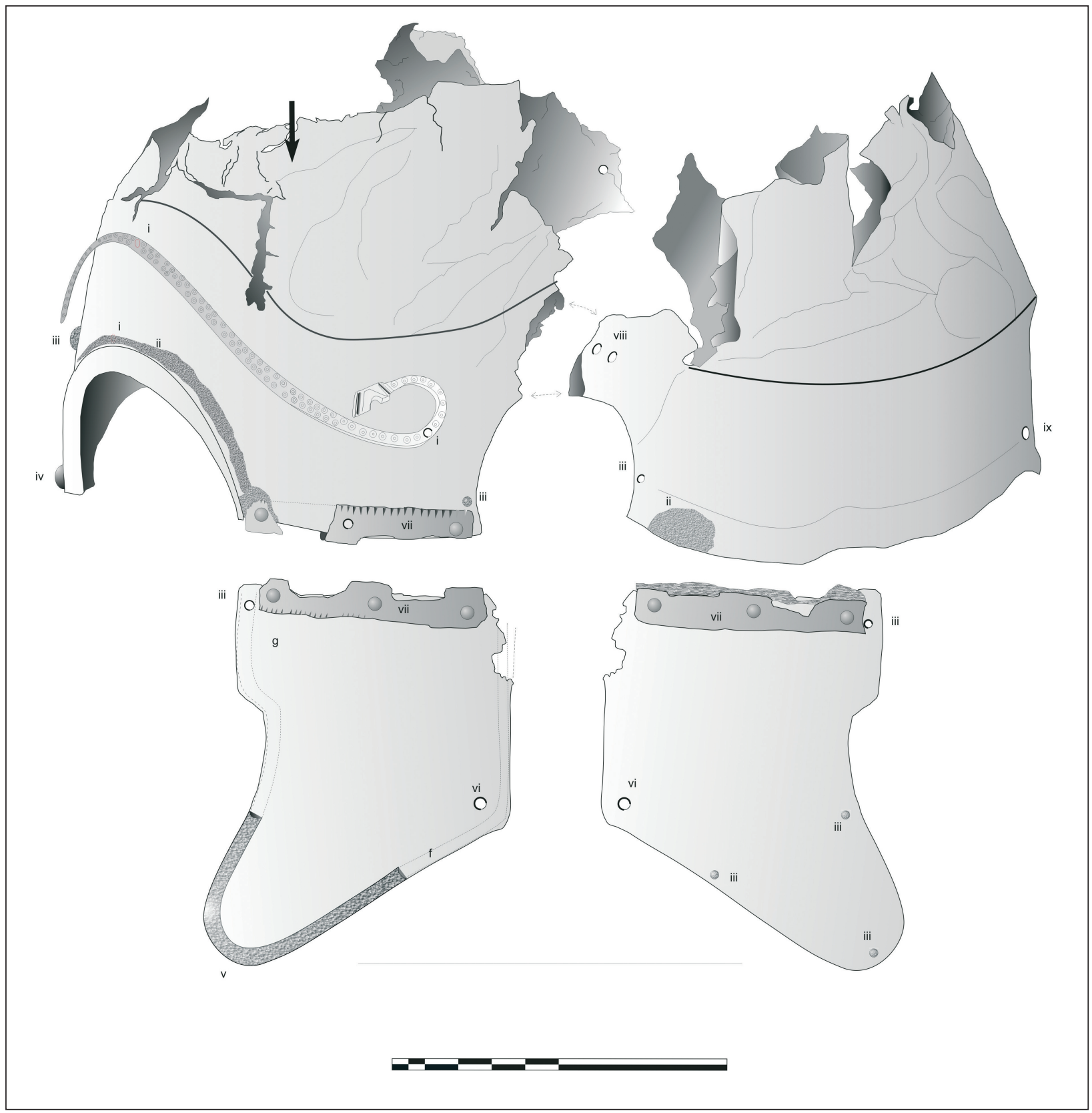

Figura 17.- Casco de Los Canónigos, dibujo del lateral izquierdo 
La posición y número de los golpes en el casco de Canónigos, como en Pozo Moro, permiten a nuestro juicio descartar daño en combate. Sin embargo, y a diferencia de los cascos de tipo Montefortino que en las tumbas ibéricas aparecen sistemáticamente despojados de sus carrilleras (Quesada 1997:571), el casco de Canónigos, como los de Numancia o Muriel que luego comentaremos, fue depositado con ellas. Otros cascos documentados en necrópolis celtibéricas aparecieron también muy aplastados y fragmentados, y aunque no se puede certificar en todos destrucción intencional, sí -hay al menos en apariencia- huellas adicionales de golpes de espada en el casco de la Sep. 'A' de Aguilar de Anguita (Barril, 2003:16).

Pese a su estado, los rasgos generales y los detalles del casco son bien discernibles. No es posible sin embargo proporcionar con alguna precisión las dimensiones básicas habituales (eje mayor antero-posterior o del plano sagital, eje menor o del plano coronal y altura) dado el muy elevado grado de deformación.

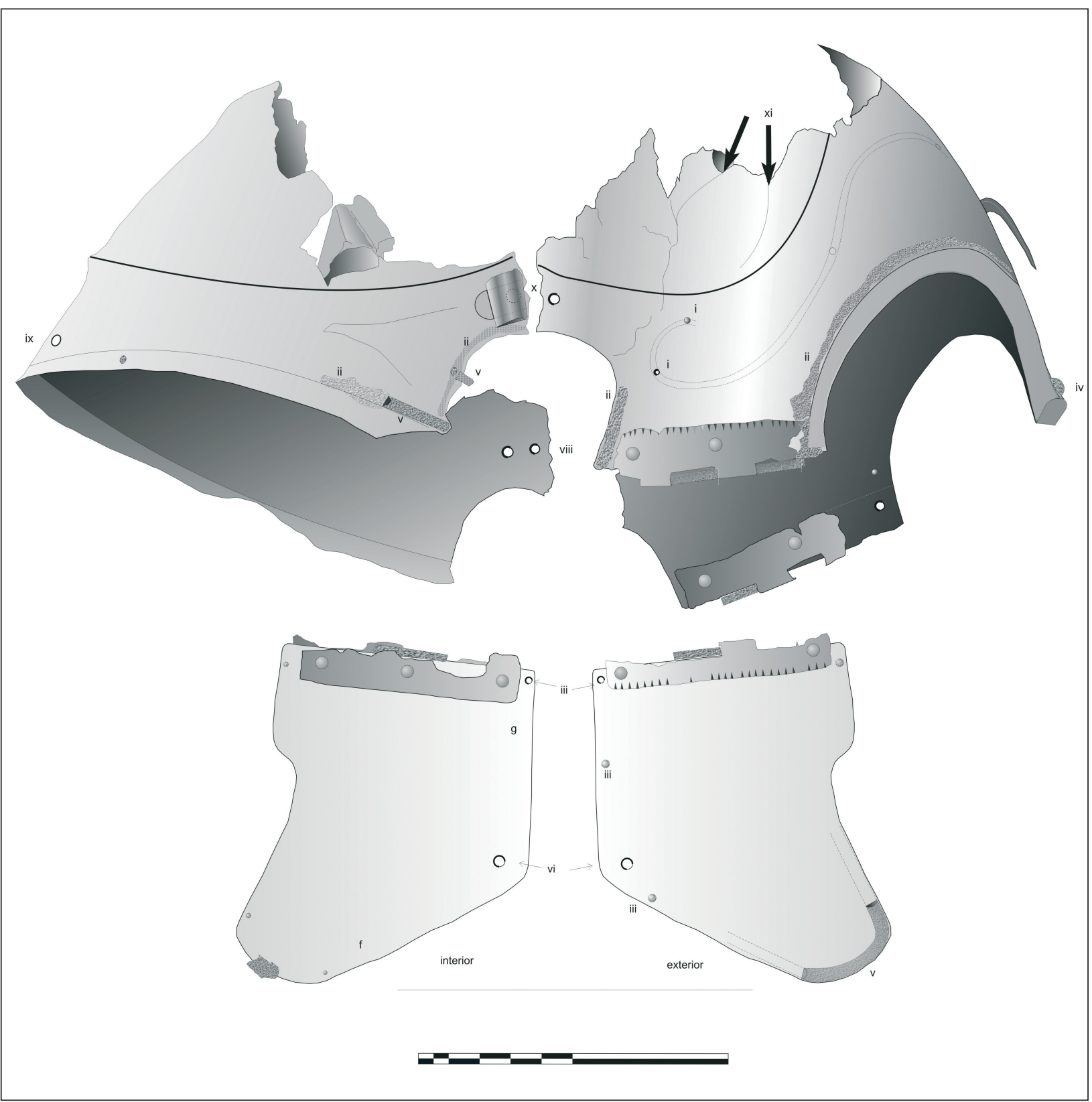

Figura 18.- Casco de Los Canónigos, dibujo del lateral derecho (ver pie de la figura 16 para la leyenda). 


\section{Fabricación y composición.}

Se trata de una pieza de bronce batido, con elementos aplicados en bronce y en hierro mediante remaches, no soldadura. La calota del casco está realizada partiendo de una sola lámina de bronce, procedimiento habitual en todo el ámbito mediterráneo para los cascos, aunque en fases antiguas se conocen piezas hechas sobre dos mitades unidas en el plano sagital (i.e., de la nuca a la frente) y a veces reforzadas allí con una tira de bronce o hierro remachada, técnica primitiva que encontramos en contextos de la Península Ibérica (por ejemplo el ya mencionado casco de Aguilar de Anguita, pero que se documenta también en cascos griegos, sobre todo los ilirios del s. VII a.C. pero incluso en alguno de tipo 'corintio', usualmente considerados paradigmas del casco hecho con una sola pieza batida sobre un soporte (i.e. el casco del Lowie Museum de Berkeley, Cal., Weiss 1977), y sobre todo en cascos italo-griegos e itálicos a secas (Weiss 1977:203).

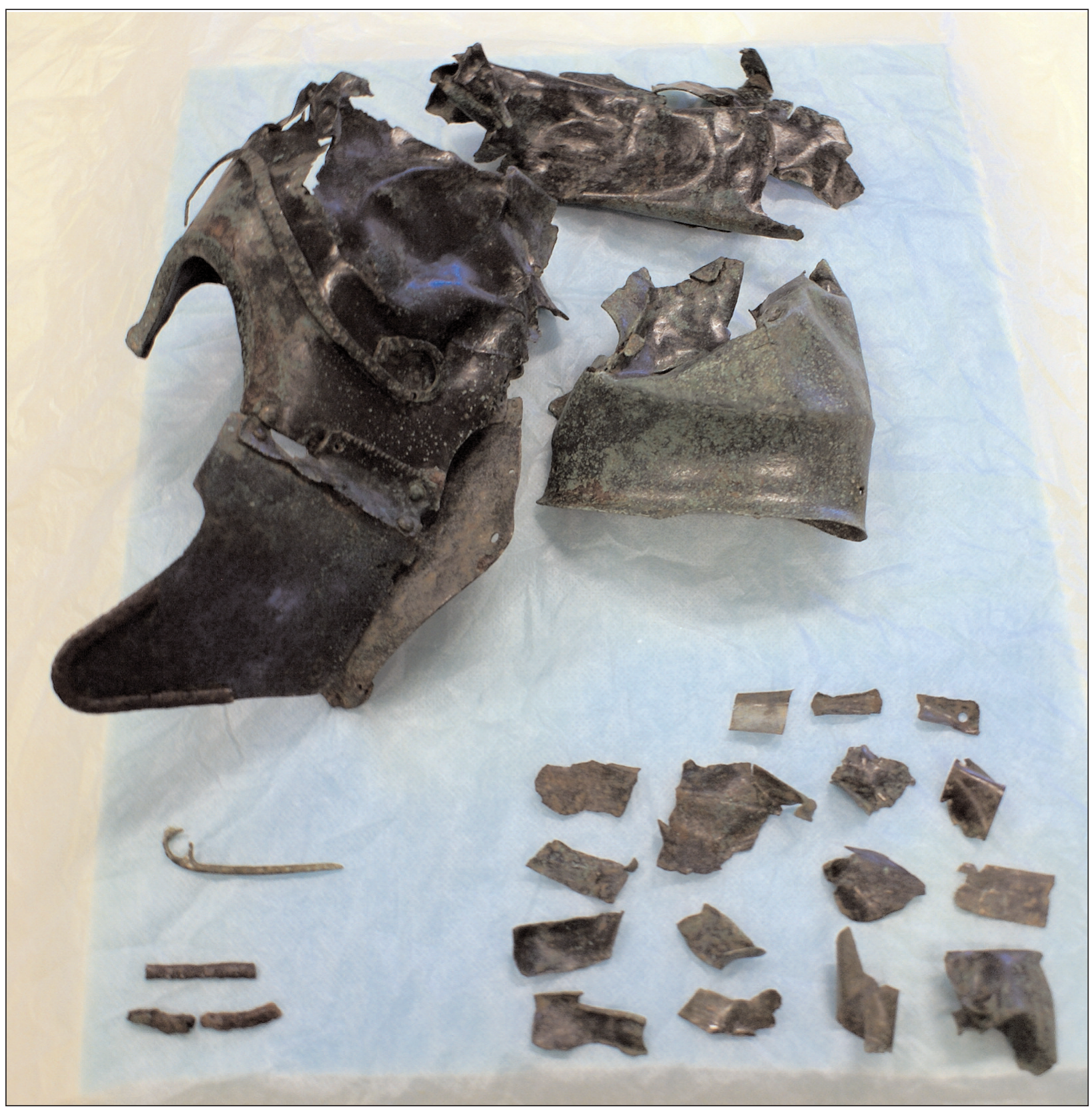

Figura 19.- Conjunto del casco de los Canónigos tras su restauración, con las piezas no reintegrables. 


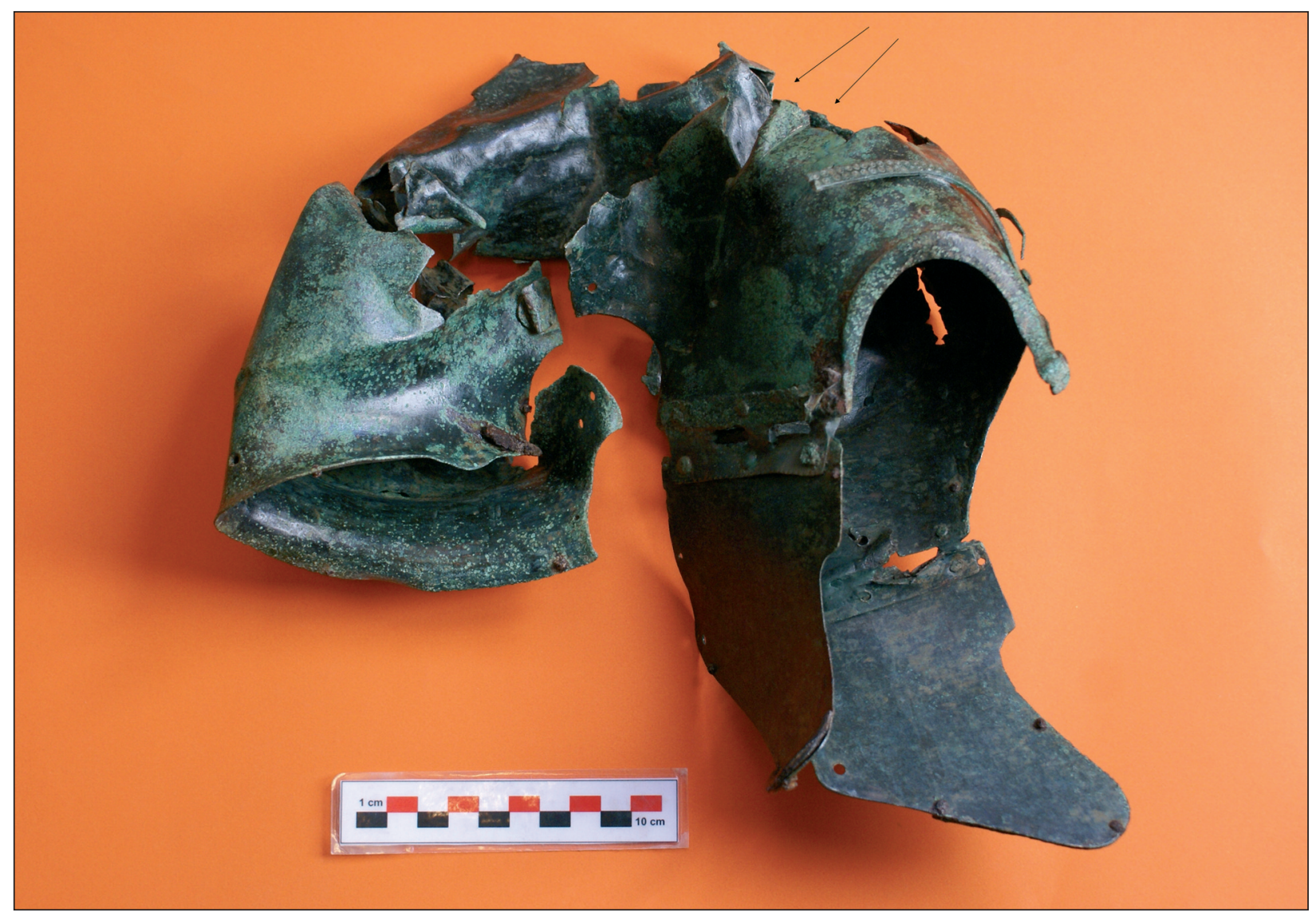

Figura 20.- Casco restaurado, lateral derecho.

La calota es redondeada, con una carena o arista no muy marcada pero visible al ojo desnudo que a grandes rasgos separa la parte superior del cráneo (frontal y parietal) del resto, y que aporta cierta elegancia al diseño. Cuenta con un guardanucas muy atrofiado y apenas discernible, sin decoración (Figuras 20, 24). La cara no queda muy protegida, ya que frontalmente (Figuras 16, 21, 23) resulta un modelo de casco bastante abierto, dotado de un corto protector nasal y un importante refuerzo en la zona de los arcos superciliares, protegiendo pues sobre todo de golpes tajantes. La parte inferior de la calota presenta a ambos lados sendas escotaduras semicirculares amplias a la altura de los pabellones auriculares, para facilitar la audición. Dos carrilleras planas y no demasiado grandes penden de sendas bisagras, protegiendo lateral -aunque no frontalmente- las mejillas y barbilla. En conjunto, se trata de un modelo bastante abierto, que permite excelente audición y visión y una buena ven- tilación, sacrificando a cambio parte de la protección pasiva.

El casco fue sometido a un proceso de restauración llevado a cabo en 2008 en el IPCE (Instituto de del Patrimonio Cultural de España), al poco de su excavación. En el proceso, una incompleta comprensión del mecanismo de bisagra de las carrilleras, o un criterio personal de restauración, llevó a una restitución en la que el conjunto aparece rígido, con una pletina plana en lugar de la delicada sucesión de ojales para un pasador de hierro (Figs. 23 y 27). Un examen detallado del original demuestra la existencia del pasador férreo y, por tanto, que no hubo una reparación antigua que hubiera, ya entonces, sustituido la carrillera articulada por otra rígida (Fig. 27).

Durante ese mismo proceso se realizó también, y en paralelo, una importante analítica (Navarro Gascón, 2008). Es de lamen- 
tar que no se tomaran varias muestras, sino sólo una esquirla con sección completa de la chapa del casco. Tampoco se realizó una prueba de dureza (con la escala Vickers, idealmente). De ese análisis resulta que se trata de un bronce binario, con un $86,3 \%$ de cobre y un $12,1 \%$ de estaño. El examen microscópico revela también huellas de recocido y de martillado, es decir, ablandamiento y endurecimiento intencionales.

No se aprecian en el interior del casco restos visibles del acolchado en fieltro, lana $\mathrm{o}$ incluso mimbre o esparto trenzado, que era habitual en los cascos antiguos para amortiguar los golpes y el efecto de 'campana' y conmoción que podría inutilizar a un combatiente incluso si el metal de su casco no resultaba perforado por un golpe (e.g. Blyth 1977:72 ss.). En la Península Ibérica tenemos al menos un ejemplo bien conservado de esa protección interior de materia orgánica en el trenzado de cestería del interior del casco del pecio griego arcaico de Cala Sant Vicenç (Alfaro 2008; Aguer et al. 2009:128 y Fig. 11). Este acolchado se podía encolar (y en tal caso no deja demasiada evidencia visible), o se podía coser a los bordes de los cascos, que en este caso presentan una delatora serie de pequeños orificios a lo largo de su perímetro, como por ejemplo en el arcaico casco corintio de la Ría de Huelva. El casco de Canónigos no muestra ni esos orificios ni restos orgánicos visibles adheridos al interior. Debemos recordar, sin embargo, que otra técnica muy común en el Mediterráneo antiguo era llevar simplemente bajo el casco un casquete o gorro de fieltro como el pilos o una banda ancha de tela ciñendo la cabeza que podía ejercer la misma función. Desde Homero (Il. 10, 255 ss.) se conocen todas estas variantes (ver e.g. Anderson 1970:29-30 y Lám. 7).

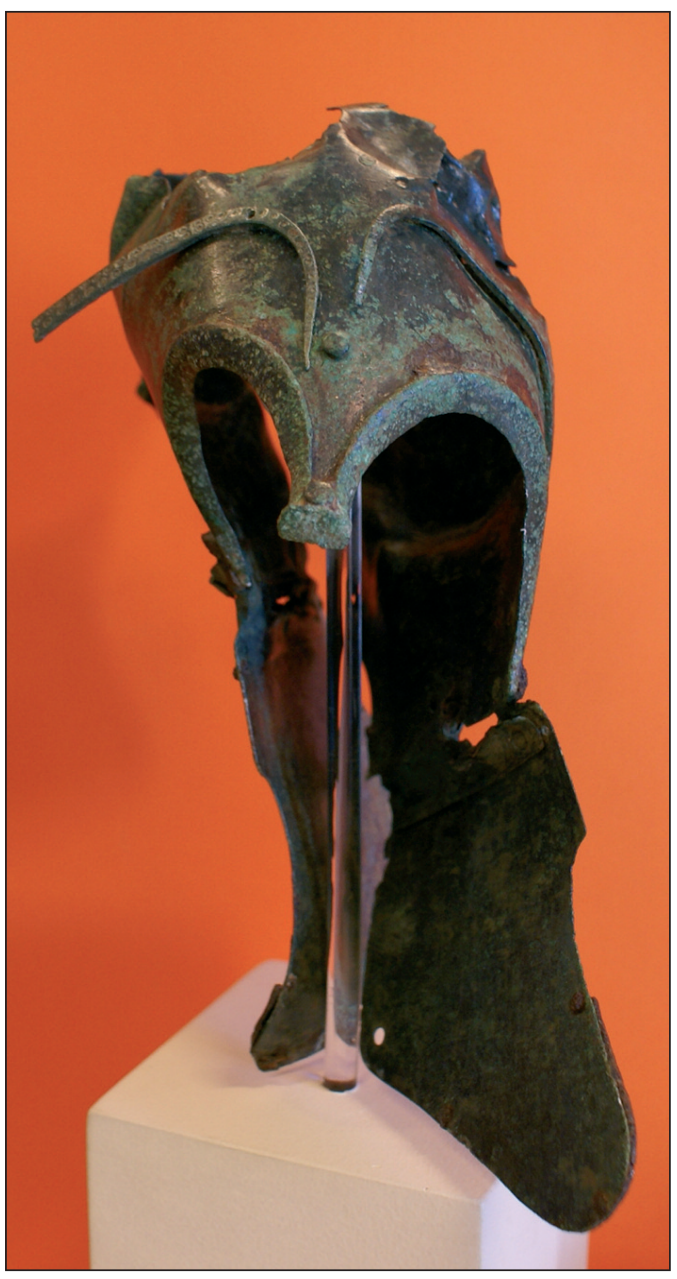

Figura 21.- Casco restaurado, vista frontal mostrando el grado de aplastamiento.

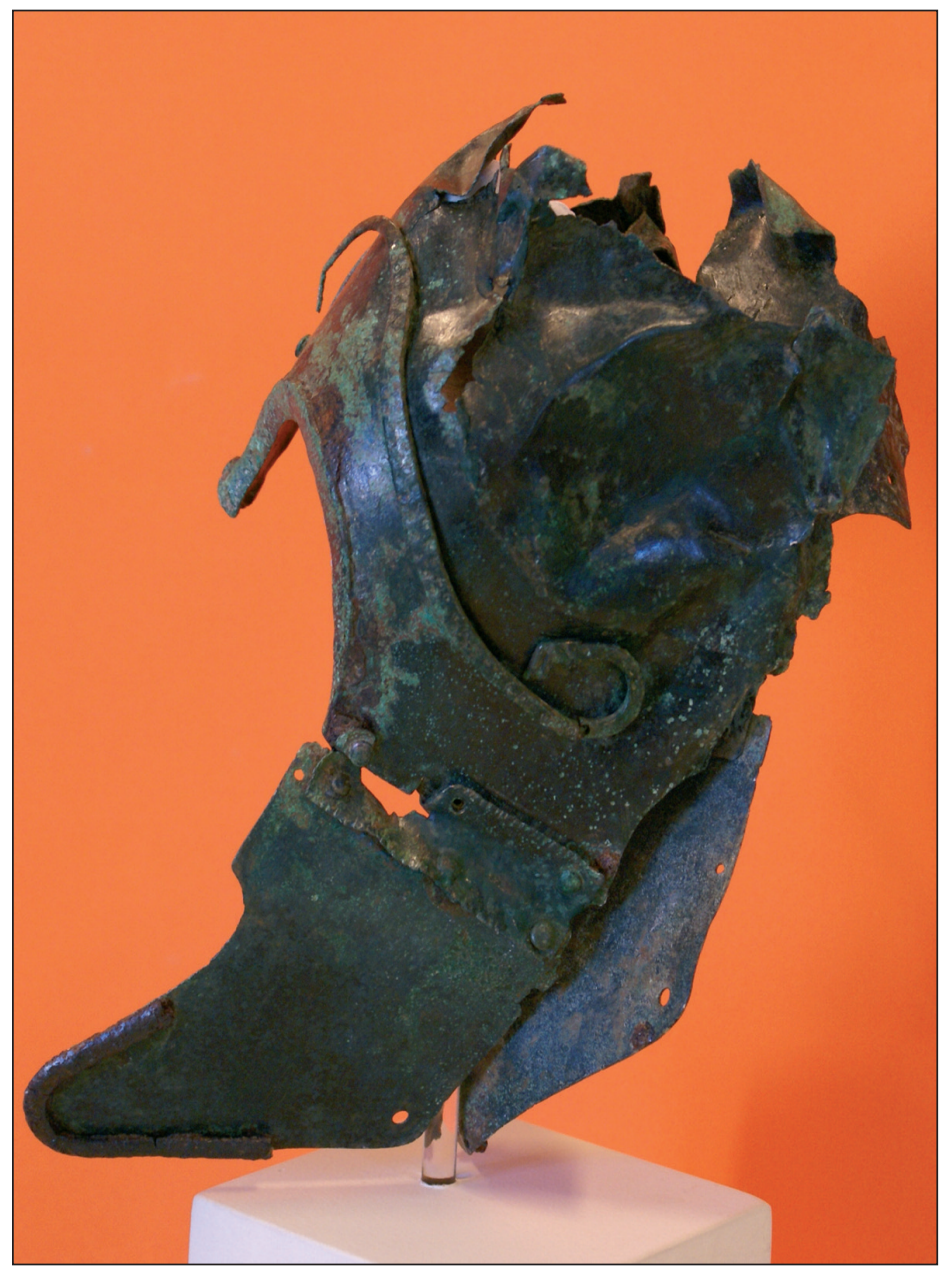

Figura 22.- Lateral izquierdo, en la foto falta la parte posterior. 


\section{Las carrilleras y su sistema de suspensión.}

El casco de Canónigos conserva sus dos carrilleras, lo que en Iberia es excepcional en los aquellos tipos de casco que las poseen, como el Montefortino-Bugennum y sus variantes, y que normalmente fueron despojados de estos protectores de la cara cuando se depositaron en sepulturas. En ello, curiosamente, coincide con los restos de un casco de tipo similar hallado en la Sepultura 39 de la necrópolis celtibérica de Numancia, donde es prácticamente solo la carrillera lo que se conserva de una pieza muy aplastada y plegada sobre sí misma (Jimeno et al. 2004:Fig. 51). En otro lugar hemos considerado (Quesada 1997:564) que quizá esta protección móvil resultara incómoda a los guerreros peninsulares, que las habrían retirado. Otra posibilidad podría ser de carácter ritual. Sin embargo, los dos cascos de este tipo de Numancia y Canónigos, ambos con sus carrilleras, y de un contexto cronológico idéntico a los Montefortinos (aunque con aparición más temprana) debe llevar a un replanteo de la cuestión que no procede aquí.

En los cascos de la familia de los Montefortino la carrillera suele articularse mediante una bisagra simple, formada por una pieza rectangular doblada sobre sí misma para dejar un hueco para el pasador y que se remacha al interior del borde inferior de la calota. Dicha pieza encaja con la parte superior de la carrillera, recortada de modo que se pliega también sobre si misma, dejando un tubo hueco central y una escotadura rectangular en el centro, para insertar en ella la pletina del casco, dejando así un tubo hueco para insertar el un pasador cilíndrico que une las dos piezas, casco y carrillera (Robinson 1975: Figs. 2-4). Esta solución se mantuvo, con variantes menores, en cascos imperiales posteriores (ibidem Figs. 35 ss.; Waurick 1988:Abb. 1A, 1B).

Por el contrario, aunque manteniendo el mismo principio de pasador cilíndrico uniendo dos piezas, el modelo de bisagra articulada del casco de Canónigos es más complejo. La pletina superior remachada al casco es más compleja, con tres remaches de sujeción y lo que probablemente fueron dos o cuatro ojales separados por tres muescas rectangulares; en cuanto a la carrillera, no es su parte superior la que se pliega, sino que a ella se remacha otra pletina similar a la unida al casco, pero en posición inversa y con tres ojales y cuatro huecos. El conjunto, una vez unido, tiene una característica forma en 'meandro'. La restauración no acabó de comprender la estructura articulada en bisagra ha reintegrado la pieza como si fuera una pletina rígida de unión entre carrillera y casco (Figs. 22 y 23), sin comprender la función del pasador de hierro ahora sólo visible al interior (Fig. 27). Esta circunstancia ha camuflado el examen visual del casco. Podría ocurrir que la parte superior hubiera tenido sólo dos elementos salientes que encajarían con los tres de la pieza de la carrillera.

El borde superior de la placa o pletina superior (la remachada al casco) y el inferior de la pletina unida a la carrillera están cubiertos por una fila de pequeñas incisiones hechas con un cincel, a modo de 'dientes de lobo' de unos pocos mm. de altura (Figs. 22 y 25). Es necesario fijarse en este detalle, por lo que su capacidad decorativa es reducida aunque evidente. Quizá su función inicial y primaria fue apretar las pletinas sobre la superficie del casco y de la carrillera, respectivamente.

A diferencia del sistema del tipo Montefortino, donde solo hay uno o dos remaches en la pletina superior, la unión entre casco y carrillera se produce a todo lo largo de la parte superior de la carrillera, unos ocho centímetros en el caso de Canónigos. La unión, aunque más compleja y mucho más elaborada, es más sólida, y sería más difícil arrancar la carrillera forzando con las manos haciendo palanca.

El sistema no es original, ya que se documenta en cascos itálicos más antiguos, como un casco calcídico de mediados del s: IV hallado en Perugia en 1935 (tumba de 
cámara en S. Giuliana) (http://www. sas.upenn.edu/ dpd/italica/armor/c-panoplies.html); o en otro italo-calcídico de Tricarico, decorado con alas y también, quizá, del s. IV a.C. (Bottini 1993:215 ss. ).

En cuanto a las carrilleras propiamente dichas (Figs. 17 y 18) son de chapa de bronce, planas, con un grosor inferior a $1 \mathrm{~mm}$., capaz sólo de frenar o desviar un golpe no demasiado fuerte y desde luego no perpendicular. Están reforzadas por el exterior, y en todo el perímetro salvo por la parte superior de unión al casco, por una tira o ribete de hierro de $5 \mathrm{~mm}$. de ancho y sección semicircular remachada al contorno por su parte plana, que debía además tener un efecto decorativo (vid. infra). No se conserva en todo el contorno (Fig. 22), pero se aprecian los orificios de fijación, algunos clavitos de hierro por el interior de las carrilleras, y una pátina perimetral de óxido de hierro adherido a la superficie broncínea.

En la parte central trasera de las carrilleras (en la parte que mira a la nuca, Figs. 17 y 18), justo donde la pieza forma un ángulo marcado, aparecen dos amplios orificios de cuatro mm. de diámetro, que, como en otros cascos similares, debieron servir para pasar las correas que, a modo de barboquejo, partían de la nuca, pasaban por las carrilleras y se unían bajo la barbilla (e.g. Robinson 1957, Fig. 10). Esta tira es similar a la que se aprecia en la carrillera del casco de Numancia citado, aunque en ese caso el aplique es de bronce y recorre la totalidad del perímetro de la misma.

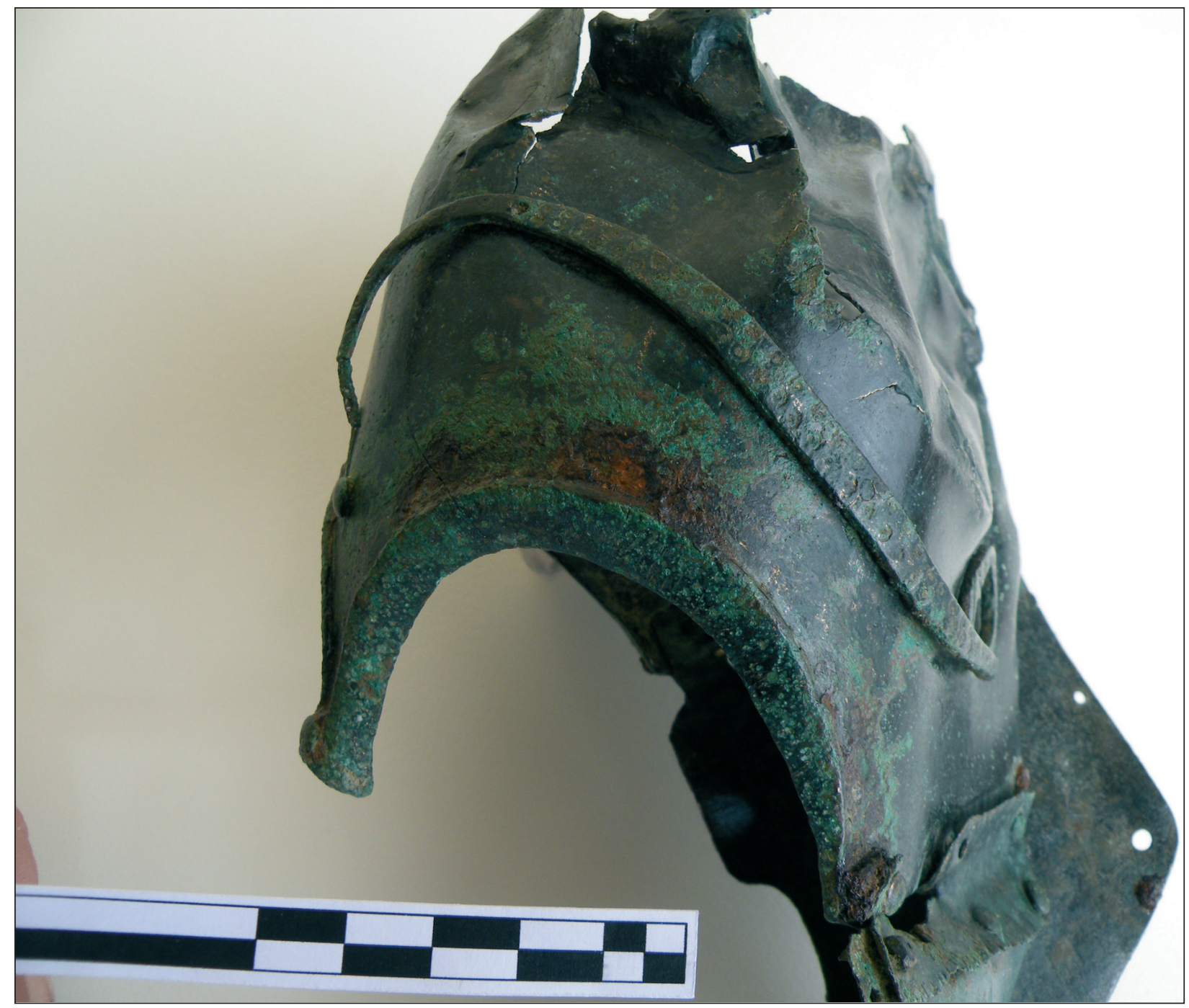

Figura 23.- Detalle frontal del casco. 


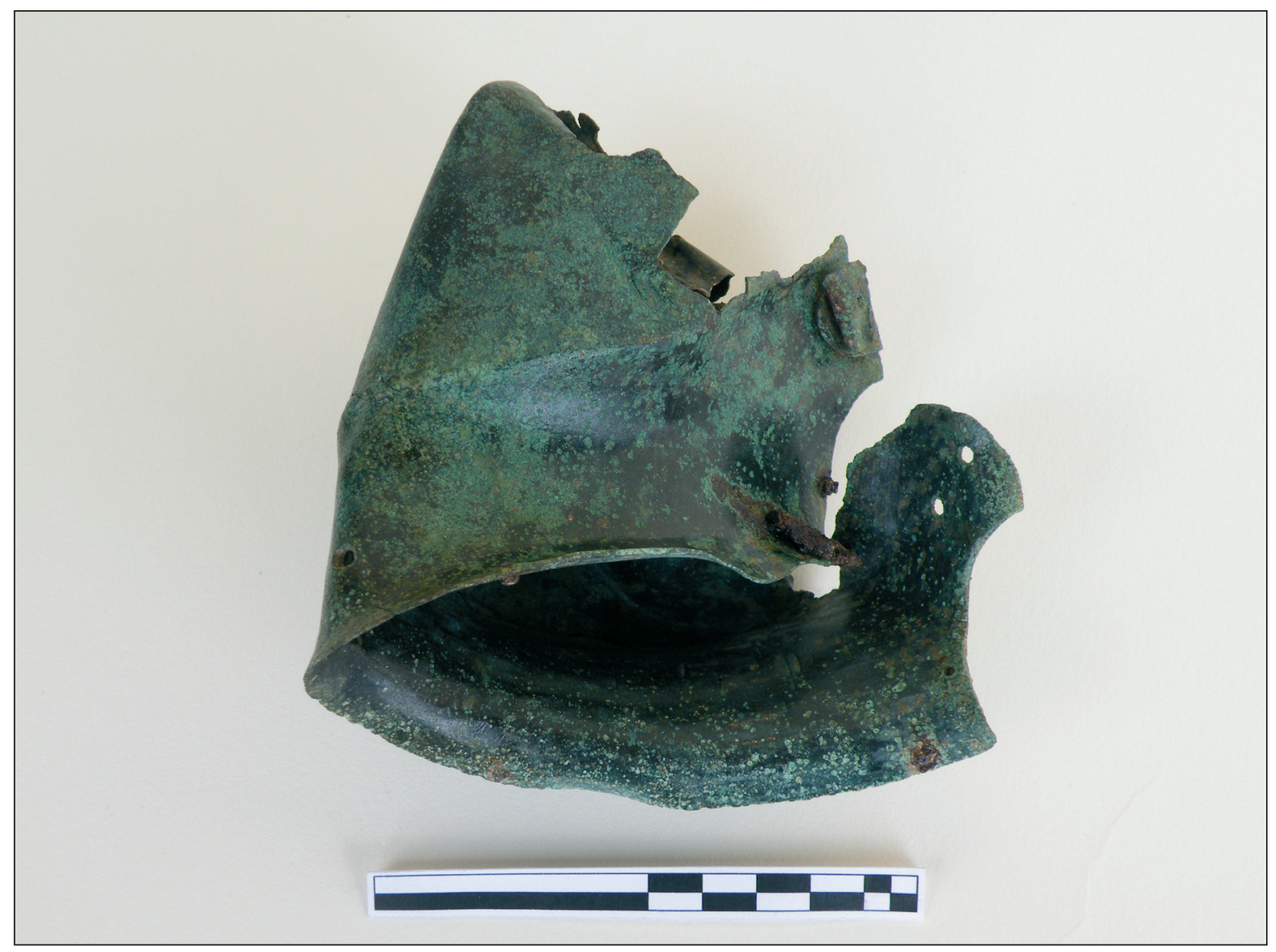

Figura 24.- Parte trasera del casco, no solidaria con la principal, pero con la que encaja.

Elementos ornamentales y de refuerzo. Decoración.

Como estamos viendo, el casco de Canónigos cuenta con una amplia serie de elementos aplicados con función básicamente ornamental y, creemos que secundariamente, de refuerzo, que probablemente sólo sea significativo en el caso de las carrilleras y contra golpes tajantes. Por el contrario, no se conserva en nuestro casco el remate (decorativo y soporte de la cresta semi-rígida o penacho flexible) que, como veremos, es característico de este tipo, probablemente, como hemos apuntado antes, porque nunca se depositó en la tumba ya que fue retirado en el momento de su inutilización ritual.

En primer lugar destacan los ribetes de refuerzo en hierro, que bordeaban no sólo las carrilleras, sino también todo el reborde de los arcos superciliares, y a lo largo del borde inferior del casco, en los laterales tras las carrilleras y en la nuca (Figuras 16, 17, 18 y 23-24). Dado que el ribete se remachó en la zona de los ojos, la parte más gruesa de la calota, una función decorativa parece tan significativa como la protectora. El ribete no se conserva en la totalidad del perímetro, pero puede seguirse también en forma de una mancha de óxido y orificios de remaches (Figs. $16,18)$.

Esta técnica se documenta en otros cascos antiguos hallados en contextos peninsulares, en particular en forma de una ribete o cinta ancha de hierro, de la que se conserva sobre todo la impronta de óxido, en el casco de varias piezas de Aguilar de Anguita (Barril 2003:12), dotado de un ancho ribete en forma de cinta ancha y plana, mucho más aparatoso que en el caso de Canónigos. Ribetes y cintas anchas de hierro remachadas sobre calotas de bronce segmentadas aparecen también en dos cascos de Alpanseque (en último lugar, Barril 2003:32 ss. con referencias anteriores), y en un ¿casco? muy peculiar de la colección Torkom Demirjian (ibidem, pp. 49 ss.), todos en todo caso de tipología y técnica muy diferente y mucho más primitiva que en Canónigos. 
En segundo lugar debemos señalar dos apliques serpentiformes, en este caso de tira de bronce se sección semicircular, que arrancan del entrecejo, sobre el nasal, recorren en curva el frente del casco, siguiendo aproximadamente el perfil de los arcos superciliares (debajo) y de la carena del casco (encima), y llegan al lateral del casco, sobre las orejas, donde se curvan sobre sí mismos (Fig. 23) y rematan en lo que parece una pezuña de bóvido (Fig. 25). A lo largo de todo su recorrido, los apliques están decorados con impresiones de círculos concéntricos, por pares donde la cinta es más ancha, en una sola fila cuando adelgaza en ambos extremos.

La función de estos apliques es a nuestro juicio claramente ornamental. Por su sujeción mediante diminutos remaches, su escaso grosor, y la atención a su decoración, no parece que su principal objetivo sea mejor la protección de la cabeza, que en este punto debe confiarse más a la propia calota y a su carena.
Uno de los dos apliques, deformado, se ha desprendido, aunque se conserva hoy restaurado y recolocado en posición forzada, testimonio de que probablemente fue arrancado cuando se inutilizó ritualmente el casco en el momento del entierro (Fig. 21).

En tercer lugar, el casco contaba a ambos lados de la cabeza, sobre la escotadura auricular (Figs. 17, 18 y 20), con dos plaquitas elipsoidales, plegadas sobre sí mismas para dejar un hueco central vertical, y unidas por dos remaches a cada lado del casco. Se conserva, dañada, la del lateral derecho, y sólo se conservan los orificios de la del lateral izquierdo. La función de esta pieza, bien documentada por la iconografía, es sujetar plumas altas que complementaban la cresta o el penacho central. Aunque en el caso concreto de esta pieza es posible que se sujetara un aplique de lámina broncínea muy liviana en forma de alta pluma, o de cuernos, como en los cascos del mismo tipo hallados en España

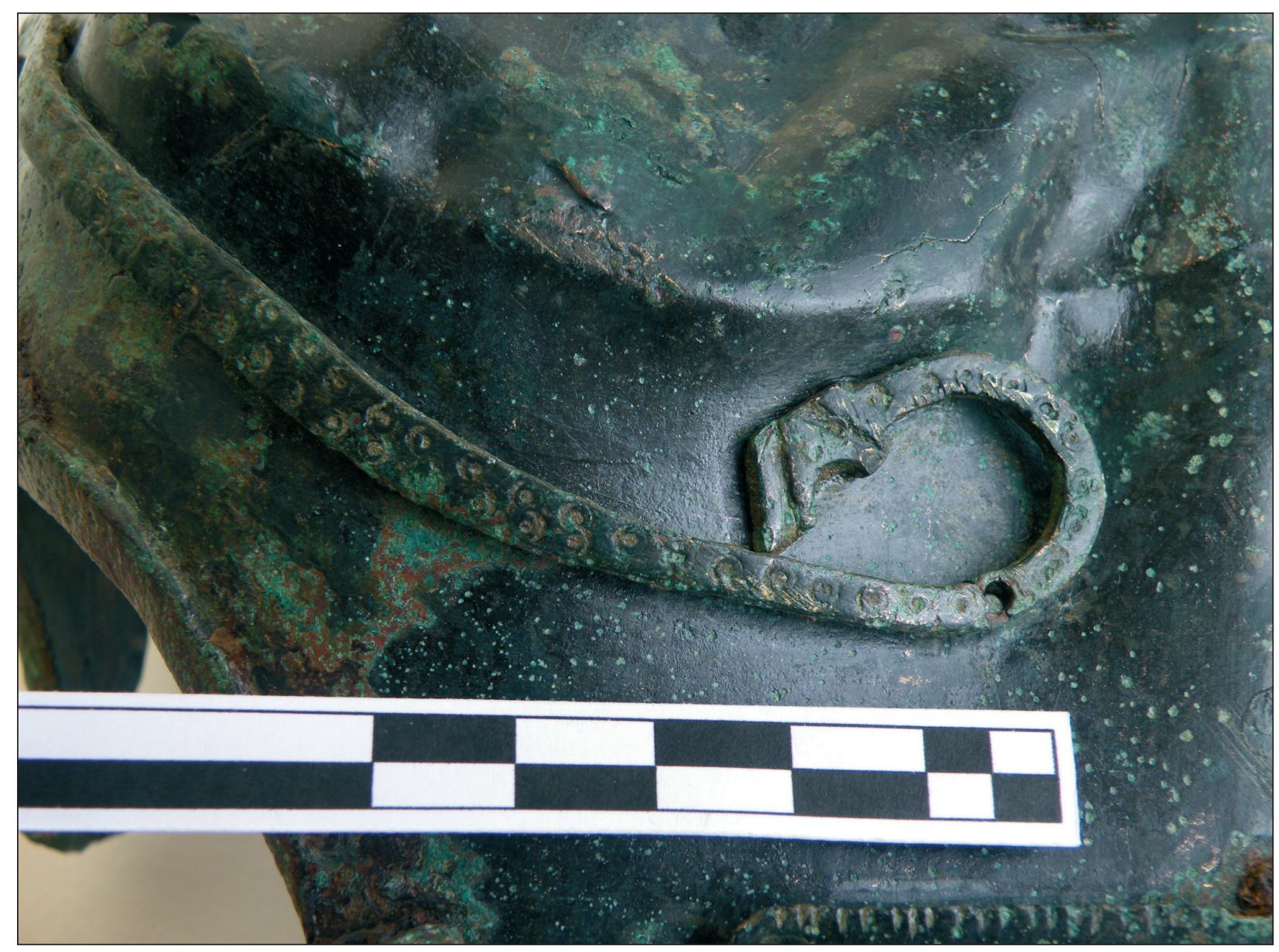

Figura 25.- Detalle de los apliques serpentiformes de la parte frontal. 
y exportados a Alemania ilegalmente, que constituyen los mejores paralelos para el de Canónigos (vid. infra).

En la Península Ibérica este sistema de sujeción de adornos laterales mediante una pletina se documenta en el ya citado casco Montefortino de la Sepultura 4F/2 de la necrópolis de Pozo Moro (Quesada 1997:Lám XIA, 1997b:156-157; Alcalá Zamora 2003:56 ss.), pieza romana con epígrafe latino de muy finales del s. III a.C. o principios del II a.C. Igualmente aparece - sin el adorno- en el casco de la espléndida fíbula Braganza de similar datación (sobre las armas de esta fíbula, Quesada 2011:Fig. 178).

Como en el caso de otros elementos, es en la Península Itálica donde encontramos los precedentes y la iconografía más relevante como prototipo, caso del guerrero pintado a caballo en una tumba de Nola, que porta un Montefortino decorado en los laterales con un espectacular par de cuernos de lámina, obviamente metálica.

En todo caso, los cascos con cresta central y dos plumas o adornos laterales parecen haber sido populares en Iberia, y quizá estén en el origen de la mención de Estrabón acerca de los cascos con tres cres-

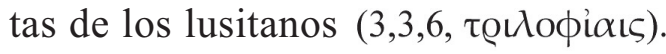

La parte superior del casco ha desaparecido, y con ella, según hemos dicho, el soporte porta-cresta que probablemente lo remataba. En otros cascos conservados de este tipo, los remaches sobre el nasal (Fig. 16) servían para sujetar anillas móviles $u$ otros elementos que contribuirían a disponer una cresta anteroposterior. No en este caso, donde los remaches de bronce no dejan hueco para sujetar elemento alguno. Aquí solo parecen tener una función decorativa, quizá como elementos atrofiados. El remache para la anilla móvil estaba aquí en

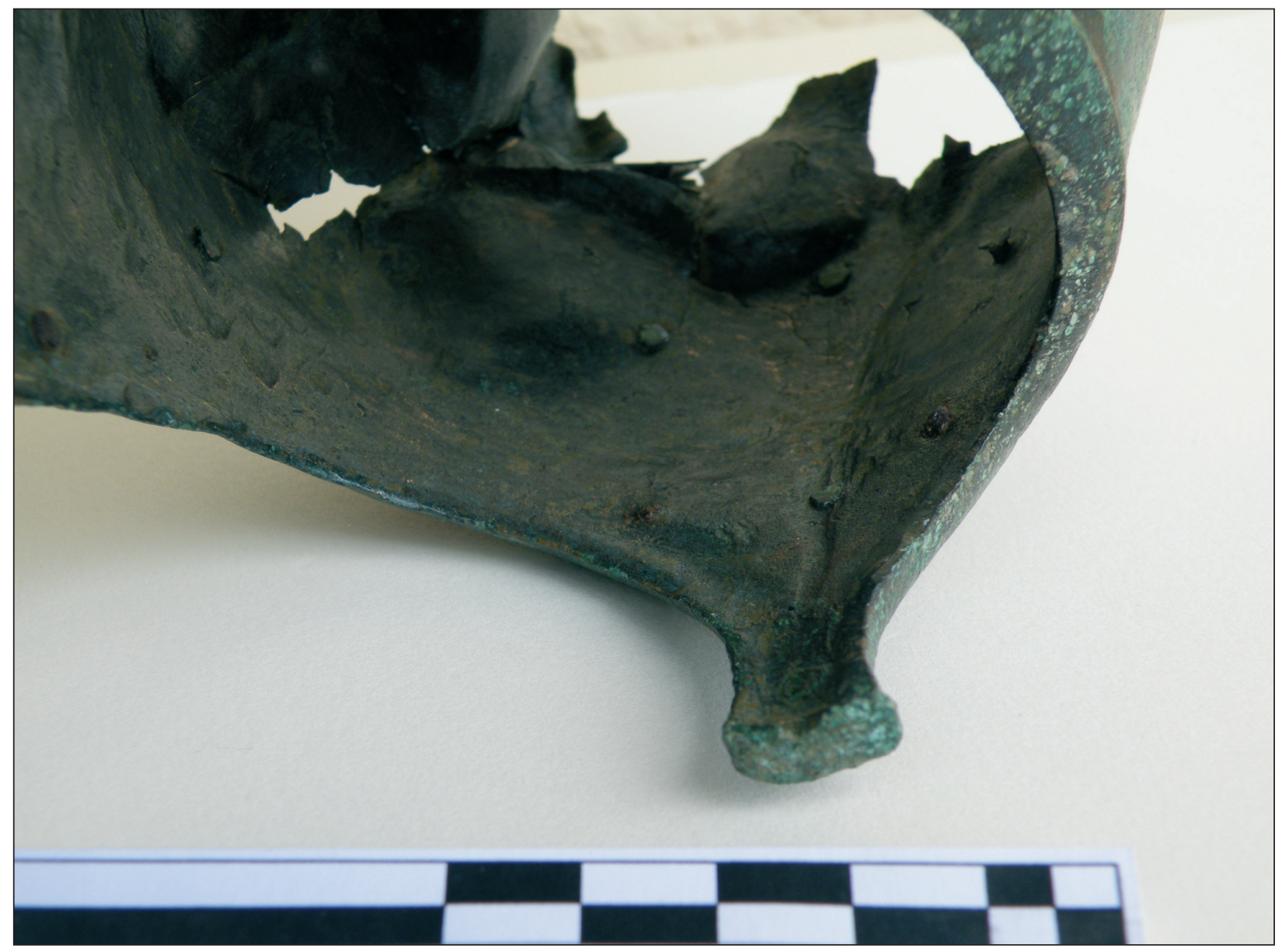

Figura 26.- Interior de la zona del nasal. 
una posición más alta sobre la frente (Fig. 16.iv).

Todos las piezas que venimos describiendo, aplicadas con remaches a la superficie del casco, forman un patrón hexagonal característico que es incluso más visible por el interior que por el exterior (Figura 26) y que puede ser empleado como criterio a la hora de juzgar la autenticidad de una pieza. El patrón está compuesto (Fig. 16) por dos clavos de cabeza redondeada en el eje del nasal, quizá el superior un elemento de soporte de la cresta, y cuatro clavitos menores a los lados, dos destinados a sujetar el ribete de hierro inmediatamente por encima del arco superciliar, y los otros dos, más arriba, para contribuir a fijar los apliques serpentiformes.

En conjunto, pues, y aunque los elementos puramente decorativos son escasos, la cantidad de apliques y pletinas remachadas, junto con la sutil decoración impresa e incisa, poco visible a distancia, sobre los serpentiformes y las pletinas de las bisagras de las carrilleras, y junto con la elegante línea de refuerzo supraorbital y la carena de la calota, contribuyen a dar la impresión de un casco muy elaborado, ciertamente más complejo y elegante que los Montefortino y Buggenum que estamos habituados a ver en contextos ibéricos y celtibéricos. Su línea es claramente itálica, pero determinados detalles, como los serpentiformes y su decoración, apuntan a una fabricación local.

Grosor de la lámina metálica y capacidad funcional del casco.

Como es normal en estos cascos de metal batido manualmente, el grosor de la lámina varía sustancialmente de una parte a otra, y de manera intencional. En el caso del casco de Canónigos, la parte más reforzada es sin duda el nasal y la zona de los arcos superciliares. Allí (Figura 16, 'a') llega a los 5-6 mm.; a

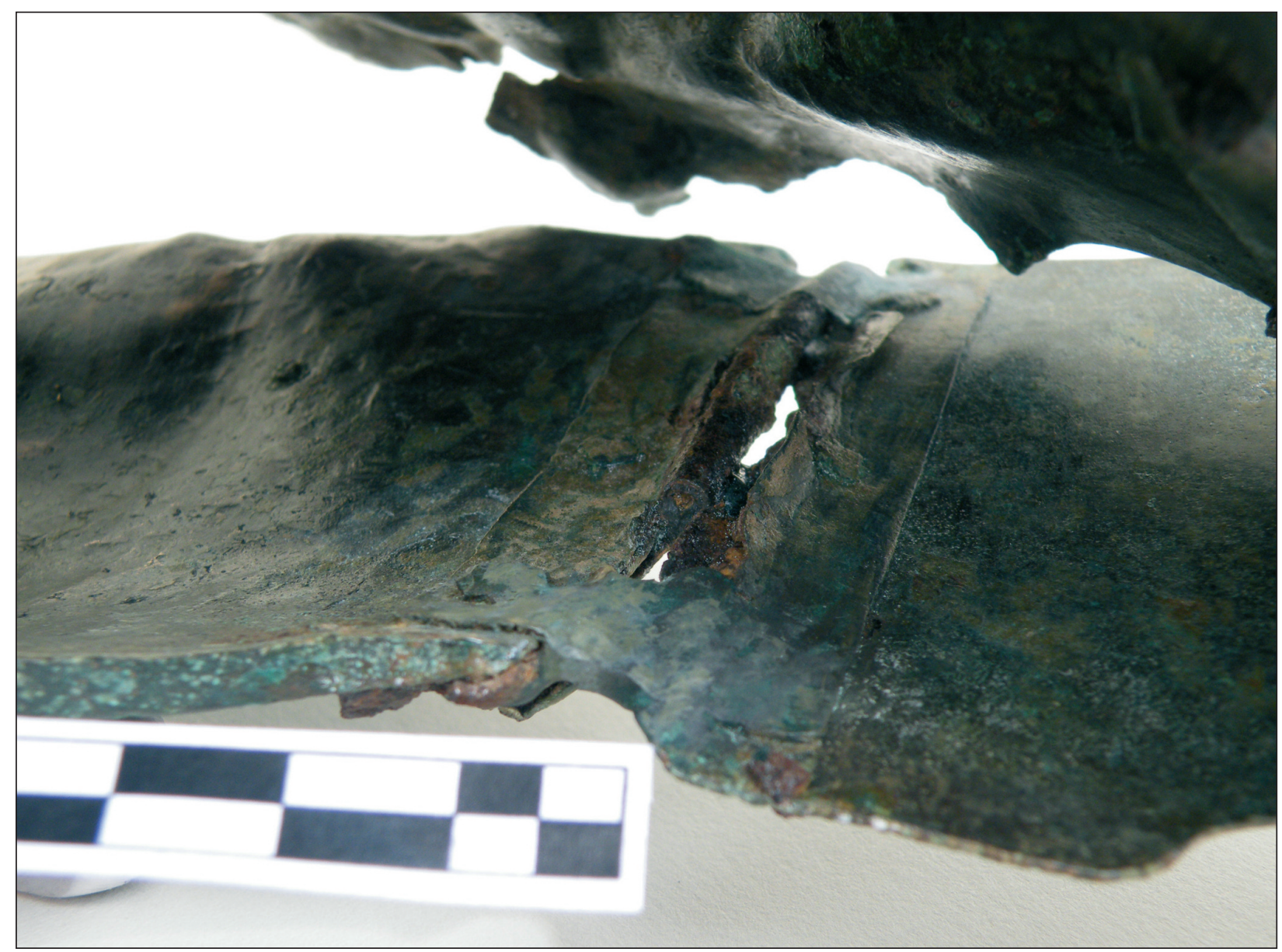

Figura 27.- Detalle de la restauración, excesiva, de la bisagra de la carrillera. Se ha perdido la articulación original. 
medida que ascendemos por la calota el grosor desciende a $3 \mathrm{~mm}$ en la zona de la frente (Fig. 16, 'b'), y a $1 \mathrm{~mm}$. en la parte superior de la calota (Fig. 16, 'c'). En el lateral, el grosor es de casi $2 \mathrm{~mm}$ justo sobre las carrilleras (Figura 18, 'd') y de $1 \mathrm{~mm}$. sobre la oreja, ya en la parte de la calota por encima de la arista, unificándose con la parte frontal superior del casco (Figura 18, 'e'). Las carrilleras son más delgadas, con un espesor de chapa de $0,6 \mathrm{~mm}$. en el extremo inferior (Figura 18 ' $\mathrm{f}$ ') y de algo más, en torno a 0,8 $\mathrm{mm}$. en la parte alta (Figura 18 ' $\mathrm{g}$ '). A estos grosores habría que añadir lo que pueda haberse perdido por la acción del óxido y la limpieza mecánica durante la restauración, aunque dado el relativo buen estado del metal (no de su forma aplastada) la proporción debe ser baja. En la Figura 26 se aprecia el grosor y solidez de la zona del nasal y arcos superciliares de la calota, capaces de resistir un golpe tajante fuerte.

Como ha valorado también recientemente Pastor (2005-6:268 ss.) a título de ejemplo, podemos comparar estos valores con otros casos, para contextualizar. El casco de Aguilar de Anguita (fechable en el s. V a.C., Lorrio 1994; Quesada 1997) presenta una chapa de en torno a $0,8 \mathrm{~mm}$. de grosor, que llega a $4 \mathrm{~mm}$ en los rebordes (Barril 2003:10). El casco simple de forma cónica de cala SantVicenç tiene un grosor de $0,9 \mathrm{~mm}$. y un peso de 1.870 gr., incluyendo el revestimiento interno (Alvarez Arza 2008:199).

H. Born y S. Hansen (1994:109 ss.) proporcionan algunas medidas interesantes en su estudio de los cascos griegos arcaicos de la colección A. Guttman. El Kegelhelm n. AG 444 pesa 960 gramos, con chapa de 1,5 $\mathrm{mm}$. bastante homogénea, cosa razonable si se tiene en cuenta que se hizo con varias láminas curvadas y remachadas entre sí, en un modelo muy arcaico de influencia oriental. Sin embargo, la construcción de los cascos metálicos del Mediterráneo cambió enseguida, y sustancialmente. Hace ya años que P. Blyth, en su Tesis doctoral (lamentablemente inédita) sobre la efectividad de la protección corporal contra las armas ofensivas en las Guerras Médicas (Blyth 1977) realizó un estudio sobre los cascos griegos del final del arcaísmo que prestaba la debida atención al grosor del metal. Estudió una muestra de nueve cascos del periodo de las Guerras Médicas, a principios del s. V a.C. , con resultados coherentes, entre los que destaca la evidencia de que el grosor es irregular e intencionado (Blyth 1977: Table $3.1 \mathrm{y}$ pp.71 ss.) La mayoría de los cascos alcanza su mayor grosor en la zona del nasal (entre 2,75 y $5 \mathrm{~mm}$.); luego en la zona de la frente y mejillas (entre 0,75 y $1.5 \mathrm{~mm}$.), mientras que los grosores menores, incluso por debajo de $1 \mathrm{~mm}$., quedan para la parte superior y la nuca. Tanto la distribución como los espesores son comparables a los del casco de Canónigos. El trabajo de Blyth concluye que, desde el punto de vista de la chapa metálica, los cascos metálicos de tipo corintio proporcionaban adecuada protección contra las flechas persas (Blyth 1977:195; 1988, 1993), aunque, dado que las láminas de menos de $1,5 \mathrm{~mm}$. son demasiado delgadas y en el caso de Grecia a menudo se ablandaron intencionalmente por recocido quizá para proporcionar más resiliencia a costa de la dureza de la chapa (Blyth 1983:293 ss.).

El estudio más reciente de Jarva sobre las corazas metálicas arcaicas concluye que los grosores típicos de en torno a $1 \mathrm{~mm}$. para los petos y otros elementos no son suficientes para detener un golpe de lanza asestado con fuerza y eficacia, pero sí son adecuados para las circunstancias normales del combate (Jarva 1995:140 ss.)

En cuanto a los cascos de tradición itálica, más tardíos, contamos con un repertorio de pesos de una colección de cascos sometida a los mismos criterios homogéneos de restauración y reintegración, la antigua colección. A. Guttmann hoy dispersada en subastas, que incluye un elevado número de cascos de tipo Montefortino bastante completos, cuyos datos resumimos en la siguiente tabla (omitimos los cascos romanos imperiales de la colección, en peor estado y de tipos ya muy diferentes (datos de Junkelmann 2000a): 


\begin{tabular}{|c|c|c|c|c|}
\hline Tipo & Inventario & Peso & Grosor & Observaciones \\
\hline \multirow[t]{5}{*}{$\begin{array}{l}\text { Montefortino Canosa/ } \\
\text { Coarelli B/Robinson A }\end{array}$} & AG 441 & 2010 gr. & $2-3 \mathrm{~mm}$. & $\begin{array}{l}\text { c. } 350-c .250 \text { a.C. } \\
\text { Con carrilleras }\end{array}$ \\
\hline & AG 323 & $1895 \mathrm{gr}$. & $2-3 \mathrm{~mm}$. & $\begin{array}{l}\text { c. } 350 \text {-c. } 250 \text { a.C. } \\
\text { Con carrilleras }\end{array}$ \\
\hline & AG 425 & $2204 \mathrm{gr}$ & $2-3 \mathrm{~mm}$. & $\begin{array}{l}\text { c. } 350 \text {-c. } 250 \text { a.C. } \\
\text { Con carrilleras }\end{array}$ \\
\hline & AG 542 & $1180 \mathrm{gr}$. & $1-3 \mathrm{~mm}$. & $\begin{array}{l}\text { c. } 350-\text { c. } 250 \text { a.C. } \\
\text { SIN carrilleras }\end{array}$ \\
\hline & AG 181 & $868 \mathrm{gr}$. & $\begin{array}{l}1-1,5 \mathrm{~mm} \\
3,5 \mathrm{~mm} \text {. borde }\end{array}$ & $\begin{array}{l}\text { c. } 300-250 \text { a.C. } \\
\text { SIN carrilleras }\end{array}$ \\
\hline \multirow[t]{2}{*}{$\begin{array}{l}\text { Montefortino Cremona/ } \\
\text { Coarelli C/ Robinson A }\end{array}$} & AG 130 & 1315 gr. & $\begin{array}{l}2,5 \mathrm{~mm} . \\
5 \mathrm{~mm} . \text { borde }\end{array}$ & $\begin{array}{l}\text { c. } 300-200 \text { a.C. } \\
\text { SIN carrilleras }\end{array}$ \\
\hline & AG 290 & $1180 \mathrm{gr}$ & $\begin{array}{l}1-2 \mathrm{~mm} . \\
4,5 \mathrm{~mm} \text {. borde }\end{array}$ & $\begin{array}{l}250-200 \text { a.C. } \\
\text { SIN carrilleras }\end{array}$ \\
\hline \multirow[t]{3}{*}{$\begin{array}{l}\text { Montefortino Rieti/ } \\
\text { Coarelli D/ Robinson B }\end{array}$} & AG 597 & $984 \mathrm{gr}$ & $1-2 \mathrm{~mm}$. & $\begin{array}{l}\text { c. } 150-50 \text { a.C. } \\
\text { SIN carrilleras }\end{array}$ \\
\hline & AG 266 & $680 \mathrm{gr}$. & $1-1,5 \mathrm{~mm}$. & $\begin{array}{l}\text { c. } 125-50 \text { a.C. } \\
\text { SIN carrilleras }\end{array}$ \\
\hline & AG 310 & 960 gr. & $1,5-3 \mathrm{~mm}$. & SIN carrilleras \\
\hline \multirow[t]{8}{*}{$\begin{array}{l}\text { Montefortino Buggenum/ } \\
\text { Coarelli D/Robinson C }\end{array}$} & AG 545 & $920 \mathrm{gr}$. & $1-2 \mathrm{~mm}$. & $\begin{array}{l}\text { c. } 50 \text { a.C.-10 d.C. } \\
\text { SIN carrilleras }\end{array}$ \\
\hline & AG 440 & $664 \mathrm{gr}$. & $1-1.5 \mathrm{~mm}$. & $\begin{array}{l}\text { c. } 50 \text { a.C.-10 d.C. } \\
\text { SIN carrilleras }\end{array}$ \\
\hline & AG 540 & 1000 gr. & $1-2 \mathrm{~mm}$. & $\begin{array}{l}\text { c. } 50 \text { a.C.-10 d.C. } \\
\text { SIN carrilleras }\end{array}$ \\
\hline & AG 536 & 666 gr. & $1-1.6 \mathrm{~mm}$. & $\begin{array}{l}\text { c. } 50 \text { a.C.-10 d.C. } \\
\text { SIN carrilleras }\end{array}$ \\
\hline & AG 537 & $736 \mathrm{gr}$. & $1-1,5 \mathrm{~mm}$. & $\begin{array}{l}\text { c. } 50 \text { a.C.-10 d.C. } \\
\text { SIN carrilleras }\end{array}$ \\
\hline & AG 541 & $954 \mathrm{gr}$. & $1-2 \mathrm{~mm}$. & $\begin{array}{l}\text { c. } 50 \text { a.C.-10 d.C. } \\
\text { SIN carrilleras }\end{array}$ \\
\hline & AG 297 & 876 gr. & $1-1,5 \mathrm{~mm}$. & $\begin{array}{l}\text { c. } 20 \text { a.C.-10 d.C. } \\
\text { SIN carrilleras }\end{array}$ \\
\hline & AG 538 & $864 \mathrm{gr}$. & $0,7-1,6 \mathrm{~mm}$. & $\begin{array}{l}\text { c. } 10 \text { a.C. }-50 \text { d.C. } \\
\text { SIN carrilleras }\end{array}$ \\
\hline
\end{tabular}

El peso actual de todos los elementos del casco de Canónigos es de 952 gramos, lo que le convierte en una pieza relativamente liviana. Curiosamente, es exactamente el mismo peso, al gramo, del casco de idéntico tipo de la Colección Varez-Fisa en el Museo Arqueológico Nacional (num. inv.
18999/99/168, agradecemos el dato a la Dra. P. Cabrera) sobre cuya autenticidad se han vertido algunas dudas que cada vez parecen más infundadas. Lógicamente, en el caso del casco de Canónigos, como en el del MAN/Varez-Fisa, habría que añadir un porcentaje difícil de precisar, pero probablemen- 
te inferior al $10 / 15 \%$, de material perdido o alterado químicamente, así como el peso del acolchado interior, si lo hubo.

Sea como fuere, resulta el de Canónigos un casco relativamente liviano para su volumen, ya que la mayoría de los cascos de similar entorno cultural y cronológico están en torno a los 1.500/ 2.000 gramos, muy por encima, por no hablar de los cascos gladiatorios de época imperial romana, de diseño y función muy diferentes y pensados para combates muy breves, cuyo grosor medio es de $1,5 \mathrm{~mm}$, con zonas amplias (rebordes y visores) de 3-5 mm., con un peso total de entre 3,3 y $6,8 \mathrm{~kg}$., y un peso medio de unos $4 \mathrm{~kg}$, el doble que un casco militar normal (Junkelmann 2000b:40).

De hecho, de los datos disponibles se deduce que los cascos de tipo griego cerrados tienen un peso cercano a los 2.000 gr., y los abiertos son más livianos. En cuanto a los cascos Montefortino, los antiguos rondan en torno a los 2.000 gr. con carrilleras, quizá unos 1.500 gr. sin ellas, pero desde principios del s. II a.C. se hacen más ligeros, en torno a los 700-1000 gr. sin carrilleras, cifra comparable a la del casco de Canónigos. En conjunto, pues, el casco de Canónigos, por su grosor y peso, está en el rango medio/bajo de los cascos militares de la Edad del Hierro del ámbito circunmediterráneo.

\section{Prototipos, CRONología, entorno CUl- TURAL Y CONCLUSIONES}

Se puede considerar el casco de Canónigos como un tipo nuevo dentro del grupo de los cascos de origen griego llamados 'calcídicos'. El modelo de partida, relacionado con el tipo llamado corintio, aligerado (Kunze, 1967; Pflug, 1988:137; Feugère 1994:19; ha sido dividido en cinco tipos por H. Pflug (1988:138). Todos ellos tienen una calota carenada, carrilleras, escotadura auricular, guardanucas desarrollado y nasal. Sólo su tipo $\mathrm{V}$ tiene carrilleras articuladas y nasal atrofiado, dos de las características más llamativas de la pieza de Canonigos, pero es todavía arcaico en comparación. El grupo calcídico básico tiene una cronología amplia, que abarca, entre piezas originales y representaciones en iconografía, desde el último tercio del s. VI a fines del s. IV a.C. (Dintsis 1988), cronología replicada en las variantes itálicas (Stary 1986:25)

Desde mediados del s. V a.C. fueron apareciendo diversas variantes híbridas, a veces muy decoradas, normalmente con carrilleras articuladas (aunque también las hay rígidas en forma de cabeza de carnero), y nasal crecientemente atrofiado como los tipos corintio-calcídico, frigio-calcídico, ático-calcídico, etc. (Dintsis 1986).

En la mitad sur de Italia, tanto en la vertiente adriática (Abruzzo, etc.) como en la tirrena aparece además en torno a mediados del s. IV a.C. una amplia variedad de cascos de tipo (sur)italo-calcídico, unos más estandarizados con carena en la calota o con unas volutas estilizadas (Cahn 1989:41; Tagliamonte 2003:158 ss.; Graells 2011), y otros de fantasía con apliques como alas laterales (Cahn 1988), portaplumas triples, incluso casos compuestos con una sólida cresta metálica anteroposterior (Bottini 1993:215 ss.) u otros rasgos que hacen difícil una clasificación. Algún autor ha denominado cascos de este tipo, a nuestro juicio discutiblemente, como ‘samno-ático’ (Burns 2003:Fig. 3).

El casco de Canónigos, sin embargo, no puede ser incluido dentro de ninguno de estos tipos, y debe ser añadido como representante de un tipo nuevo, hispano, que comienza a ser bien conocido en la Península Ibérica (Pastor 2006-6). Ya hemos mencionado en varias ocasiones el directo paralelo de Numancia (Jimeno et al. 2004), y otros varios. El conjunto de los cascos conocidos (o más bien de sus fragmentos) ha sido recogido, con un estimable estudio preliminar, por Pastor Eixarch (2005-2006 y 2012 e.p.), e incluye los ejemplares de Muriel de la Fuente (Soria) y otros, todos ellos bien conocidos de antiguo pero que no se habían relacionado entre sí al constar, en la mayoría de los casos, de piezas sueltas como remates (La Osera), carrilleras (Alto Chacón), etc. Con todo, el mayor conjunto de cascos de este tipo es el formado por una veintena de piezas casi completas, procedentes de Aranda de Moncayo (Zaragoza) expor- 
tadas ilegalmente de España a mediados de la década de los ochenta, que tras una serie de avatares pasaron a formar parte de la colección Axel Guttmann de Berlín y que, tras su muerte, se han ido subastando y dispersando por toda Europa. Estas piezas se han ido conociendo de manera gradual a través sobre todo de los catálogos de casas de subastas y de la prensa, y sólo se han publicado algunas referencias aisladas (Quesada 2006, Pastor 2005-6, Quesada 2010:157, 230-231) en tanto en cuanto que las autoridades competentes se hacían cargo de la reclamación del conjunto, tarea en la que hasta ahora no han tenido éxito alguno.

El examen preliminar de estas piezas en 2005 nos reveló su carácter itálico, pero las peculiaridades tipológicas, la tosca decoración damasquinada en plata aplicada sobre algunos de los cascos, y la noticia de que los cascos habían aparecido en Soria (dato erróneo que nos fue proporcionado intencionalmente o no), aplastados y colocados en grietas de la roca como si se tratara de una ofrenda votiva, fueron datos que nos llevaron a opinar que se trataba de cascos de auxiliares -socii- itálicos de las legiones romanas, capturados quizá en las campañas celtibéricas, modificados de acuerdo con el gusto local, de modo que algunos (Numancia) harían acabado en manos de guerreros celtíberos, y otros se habrían depositado en santuarios como ofrendas (Quesada 2006; 2010:231). El caso que ahora estudiamos de Canónigos, el número creciente de elementos que van surgiendo en contextos locales, y el examen más detenido del conjunto nos llevan a modificar esa impresión inicial en favor de una producción hispana. Así pues, Pastor (2005-6:275) acierta probablemente al considerar estas piezas como producciones hispanas y no itálicas modificadas localmente.

Aunque Pastor es taxativo al considerar este nuevo tipo como 'celtibérico' (2005-6, 2012), quizá sea sin embargo ir demasiado lejos, dados los casos claramente no celtibéricos de La Osera por un extremo geográfico, y los de Canónigos (inédito hasta ahora) o incluso el del Alto Chacón por el otro. Es muy cierto que la mayoría de ejemplares (Aranda,
Numancia, Muriel) proceden del área celtibérica, y que los restantes podrían considerarse exportaciones periféricas o incluso fronterizas entre la Celtiberia e Iberia (e.g. Alto Chacón, Pérez Blasco 2012) pero el estado de nuestros conocimientos es todavía embrionario, y dados los precedentes de considerar como nuclear y emisora el área celtibérica, cuando luego se ha revelado que era receptora (e.g. Quesada 1999), quizá sea por el momento preferible la más aséptica denominación 'hispano-calcídico', que entronca con la tradición mediterránea mencionada, sin tratar de adscribir la producción local a un espacio peninsular concreto, toda vez que a nuestro juicio el contexto de la necrópolis de Canónigos es en su conjunto claramente ibérico (supra).

El casco de la Sep. 39 de Numancia debe fecharse dentro del s. II a.C., y probablemente en una fase avanzada de dicha centuria, cercana al 134 a.C., a juzgar por la ubicación muy periférica y por tanto más tardía de la tumba en la dispersión espacial del conjunto (Jimeno et al. 2004:86 para el casco; Fig. 15 para la planimetría detallada, y pp. 299 ss. para la reconstrucción cronológica); el del Alto Chacón podría ser de esa fecha o incluso algo posterior, y la Sep. 201 de La Osera (Cabré y Cabré, 1933:Lám. VI) debe fecharse probablemente en la primera mitad del s. III a.C. Los Cabré ya dieron una fecha de fines del IV o principios del s. III (ibidem p. 37), e incluso si, aceptando la opinión de Sanz Mínguez (2002:97) sobre la cronología algo más antigua del puñal de tipo Monte Bernorio/Mireveche de la misma tumba, convendremos en que son los materiales de cronología más avanzada los que deben fecharla, y en ese sentido los estudios recientes más detallados tienden a volver a una fecha de fines del IV-principios del s. III a.C. (e.g. Alvarez Sanchís 1999:189; Lorrio 2008:263 se inclina también por una fecha entre fines del s. IV y principios del s. III a.C.), mientras que uno de nosotros se inclina por la horquilla más reciente de ese margen, ya a principios del s. III a.C. (Quesada 1997:Fig. 7). El trabajo más reciente y completo sobre las espadas de La Tène en Iberia tiende a fechar la espada de la Osera (de su tipo B2.1, García 
Jiménez 2011:267 ss.) dentro el s. III a.C. con una escasa posibilidad de poder subir al último momento del s. IV (ibidem 379, Fig. 87).

En conjunto, el ajuar de la Sep. 3 de Canónigos permite proponer una fecha más antigua para el casco que en los casos de Numancia o Alto Chacón. La horquilla máxima posible sería a nuestro juicio desde mediados del s. IV a.C. y hasta principios del s. II a.C. (recordemos la dificultad de datación de los elementos metálicos, Lorrio 2002:70); la probable, desde fines del s. IV a mediados del s. III a.C. A nuestro juicio, el primer tercio del s. III a.C. es una fecha muy probable. Sin embargo, de lo que no cabe duda es de que variantes de este casco seguían en uso en época de la conquista romana del Alto Duero, y de que por tanto no podemos fechar el gran conjunto de Aranda del Moncayo sólo sobre la base de los contextos conocidos más antiguos, entre los cuales se podría contar Canónigos.

En todo caso, preparamos en colaboración con R. Graells y A. Lorrio un estudio monográfico sobre el tipo de casco que analizamos, y es allí donde se discutirán con mayor detalle todos estos extremos. Por ahora, presentamos el caso del casco de Canónigos como un hallazgo de excepcional importancia, dado que es -con mucho- el mejor conservado y documentado de los muy pocos ejemplares conocidos con un contexto arqueológico, lo que nos permite avanzar tanto en el estudio cronológico como en el campo de la tipología y clasificación cultural.

\section{Bibliografía}

ALCALA-ZAMORA, L. (2003) La necrópolis ibérica de Pozo Moro. Bibliotheca Archeologica Hispana 23. Madrid.

ALFARO GINER, C. (1978) ) "Algunos aspectos del trasquileo en la Antigüedad: a propósito de unas tijeras del Castro de Montesclaros". Zephyrus 28-29, pp. 299-308.

ALFARO GINER, C. (2008) "La protección interna del casco de bronce". X. Nieto et al. (eds.) El vaixell grec arcaic de Cala Sant Vicent. Monogr. Del CASC 7, pp. 208-213. Barcelona.
ALMAGRO GORBEA, M. (1976-78) "La iberización de las zonas orientales de la Meseta". Els Origens del Món Ibèric. Ampurias 38-40, pp. 93-156. Barcelona.

ALMAGRO GORBEA, M. (1999) "Los Iberos en Castilla-La Mancha". M. A. Valero (ed.), las Jornadas de Arqueología Ibérica en Castilla-La Mancha, pp. 25-48. Toledo.

ALVAREZ ARZA, R. (2008) "El casco de bronce: estudio morfológico". X. Nieto et al. (eds.) El vaixell grec arcaic de Cala Sant Vicent. Monogr. Del CASC 7,pp. 199-208. Barcelona.

ALVAREZ SANCHIS, J.R. (1999) Los vettones. Bibliotheca Archaeologica Hispana 1, Madrid, RAH.

ANTELO, T. et al. (2008) "Informe de estudio radiográfico, $\mathrm{n}^{\circ}$ registro 23551 ”. Informe técnico inédito, Registro 23551. IPCE.

ARANEGUI GASCÓ, C., (1992): “La Necrópolis de Cabezo Lucero (Guardamar del Segura, Alicante)", Congreso de Arqueología Ibérica. Serie Varia 1, Madrid, 169-188.

ARGENTE OLIVER, J.L. (1994) Las fíbulas de la Edad del Hierro en la Meseta Oriental. EAE 168. Madrid.

ARGENTE OLIVER, J.L.; DÍAZ DÍAZ, A. y BESCÓS CORRAL, A., (2000): Tiermes $V$. Carratiermes necrópolis celtibérica, Memorias de Arqueología en Castilla y León 9, Ed. Junta de Castilla y León, Valladolid.

AULADELL MARQUES, J. (1993) "Metal.lúrgia i útils fèrrics agrícoles i ramaders preromans a l'àrea Laietana". Gala 2, pp. 227-236.

BARBERA FARRAS, J. (1969-1970) "La necrópolis ibérica de Cabrera de Mar. Excavación 19681969." Ampurias XXXI-XXXII, pp. 169-189.

BARRIL VICENTE, M. (1992) "Instrumentos de hierro procedentes de yacimientos celtibéricos de la provincia de Soria en el Museo Arqueológico Nacional". Boletín del Museo Arqueológico Nacional 10, pp. 5-24.

BARRIL VICENTE, M. (2003) "Cascos hallados en necrópolis celtibéricas conservados en el Museo Arqueológico Nacional de Madrid". Gladius 23, pp. 5-60. 
BARRIL VICENTE, M. (2012) "La necrópolis celtibérica de Las Horazas (El Atance, Guadalajara) y su nueva interpretación a la luz de la documentación”. VII Simposio sobre los Celtíberos. Nuevos hallazgos, nuevas interpretaciones. Daroca.

BERZOSA DEL CAMPO, R. (2005) "Utillaje y herramientas de trabajo de los celtíberos". Celtíberos. Tras la estela de Numancia, pp. 319-328. Soria.

BLÁNQUEZ PÉREZ, J., (1988): “Los enterramientos de estructura tumular en el Mundo Ibérico", Congreso Peninsular de Historia Antigua. Santiago de Compostela, Vol. II, 5-38.

BLÁNQUEZ PÉREZ, J., (1990): La formación del mundo ibérico en el sureste de la Meseta. (Estudio arqueológico de las necrópolis ibéricas de la provincia de Albacete), IEA, Albacete.

BLÁNQUEZ PÉREZ, J., (1992): “Las Necrópolis ibéricas del Sureste de la Meseta", Congreso de Arqueología Ibérica, Serie Varia 1, Madrid, 235278.

BLÁNQUEZ PÉREZ, J., (1993): “El Mundo funerario albacetense y el problema de la escultura ibérica: La Necrópolis de los Villares", Arqueología en Albacete. Serie Patrimonio Histórico 6, Toledo, 111-128.

BLÁNQUEZ PÉREZ, J., (1995): “El mundo funerario en la cultura ibérica”, En FÁBREGAS, PÉREZ Y FERNÁNDEZ (Eds.), Arqueologoxía da Morte. Arqueología de Morte na Península Ibérica desde as Orixes ata o Medievo, Ed. Xinzo de Limia, Orense, 249-276.

BLÁNQUEZ PEREZ, J., (1999): “Las necrópolis Ibéricas en Castilla-La Mancha”, VALERO TÉVAR, M.A., (ed.), Actas de las $1{ }^{a}$ s Jornadas de Arqueología Ibérica en Castilla-La Mancha, Serie Patrimonio Histórico. Toledo, 49-88.

BLYTH, P.H. (1977) The Effectiveness of Greek Armour Against Arrows in the Persian Wars. Unpublished Ph.D. Diss. Univ. of Reading. Reading.

BLYTH, P.H (1983) "Metallurgy of bronze armour. Use of work hardening in the late Corinthian Helmet as evidence of mastery of material". 12th International Congress of Classical Archaeology, III, pp.293-296. Athens.

BLYTH, P.H. (1988) "Metallurgie des armes de brinze". C. Rolley et al. (eds.) Techniques antiques $d u$ bronze. Centre de Recherches sur les techniques gréco-romaines. CNRS, n. 12, pp.53-58. Paris.
BLYTH, P.H. (1993) "Metallurgy of two fragmentary Archaic Greek Helmets". Journal of the Historical Metallurgy Society, 27.1, pp. 25-36.

BONET ROSADO, H.; MATA PARREÑO, C. (2002) El Puntal dels Llops. Un fortín edetano. SIP, Trabajos Varios 99. Valencia

BORN, H.; HANSEN, S. (1994) Frühgriechische Bronzehelme. Summlung Axel Guttmann. Mainz am-Rhein.

BOTTINI, A. (ed.) (1991) Gli strumenti della guerra in Basilicata fra VIII e III secolo a.C. Bari, Edipuglia.

BOTTINI, A. (1993) Armi. Gli instrumenti de la guerra in Lucania. Bari, Edipuglia.

BROTONS YAGUE, F.; RAMALLO ASENSIO, S. (2010) "Ornamento y símbolo: las ofrendas de oro y plata en el santuario ibérico del Cerro de la Ermita de la Encarnación de Caravaca". T. Tortosa, S.Celestino (eds.) Debate en torno a la religiosidad protohistórica, pp. 123-168. Madrid.

BRUNAUX, J.L.; RAPIN, A. (1988) Gournay II. Boucliers et lances, dépôts et trophées. Revue Archeologique de Picardie. Paris.

BURNS, M.T. (2003) "The homogeneisation of Military Equipment under the Roman Republic." Romanization?. Digressus Supplement (=www.digressus.org) 1, pp. 60-85.

CABRE AGUILO, J. (1929) "Excavaciones en la necrópolis celtibérica del Altillo de Cerropozo, Atienza (Guadalajara)". MJSEA 105. Madrid.

CABRE AGUILO, J.; CABRE DE MORAN, M.E. (1933) "Datos para la cronología del puñal de la cultura de 'Las Cogotas'". AEspA 24, pp. 37-47.

CAHN, D. (1989) Antikenmuseum Basel und Sammlung Ludwig. Waffen und Zaumzeug. Basel.

CERDEÑO SERRANO, M.L.; PEREZ DE YNESTROSA, J.L. de (1993) La necrópolis Celtibérica de Sigüenza: revisión del conjunto. Monografías del SAET 6. Teruel.

CHAPA BRUNET, T., (1993): "La destrucción de la escultura ibérica", Trabajos de Prehistoria 50, 185-195.

CHAPA BRUNET, T.; MAYORAL HERRERA, V. (2007) Arqueología del trabajo. El ciclo de la vida en un poblado ibérico. Madrid. 
CHARDENON, N. (2000) "Agriculture à l'Age du Fer et outillage à Mailhac (Aude)". R. Buxó, E. Pons (eds.) Els productes alimentaris... Actes XXII Colloque de l'AFEAF, pp. 281-295. Girona.

CISNEROS FRAILE, F. (1992) "Fíbulas anulares de la Casa del Monte (Valdeganga, Albacete)". Homenaje a E. Pla Ballester. SIP, Trabajos Varios 89, pp. 199-215. Valencia.

COARELLI, F. (1976) "Un elmo con iscrizione latina arcaica al museo di Cremona" Mélanges offerts à Jacques Heurgon. L'Italie prerromaine...et la Rome Républicaine, pp. 157-173. Rome.

CUADRADO DIAZ, E. (1957) "La fíbula anular hispánica y sus problemas". Zephyrus 8, pp. 5-76.

CUADRADO DIAZ, E. (1957b) "Fíbulas anulares hispánicas de la colección Vives." V CNA Zaragoza, 1955, pp. 169-179. Zaragoza.

CUADRADO DIAZ, E. (1960) "Fíbulas anulares típicas del norte de la Meseta Castellana." AEspA 33, pp. 64-97.

CUADRADO DÍAZ, E., (1987): La Necrópolis Ibérica del Cigarralejo (Mula, Murcia), Bibliotheca Praehistorica Hispana XXIII, Madrid.

DAUGAS, J.P.; TIXIER, L. (1976) "Essai de technologie et de typologie des fibules annulaires iberiques. A propos d'un exemplaire découvert au pic d'Ysson (communes de Vodable-Solignat)". Cypsela 2, pp. 121-143.

DINTSIS, P. (1986) Hellenistische Helme. Archaeologica 43. Roma.

FERNANDEZ GOMEZ, F. (2011) El poblado fortificado de El Raso de Candeleda (Avila). El núcleo D. Un poblado de la II Edad del Hierro en la Meseta de Castilla. Madrid-Sevilla-Avila.

FEUGERE, M. (1994) Casques antiques. Les visages de la guerre de Mycenes à fin de l'Empire Romain. Paris, Errance.

GABALDON MARTINEZ, M.M. (2004) Ritos de armas en la Edad del Hierro. Armamento y lugares de culto en el antiguo Mediterráneo y el mundo celta. Anejos de Gladius 7, Madrid, CSIC.

GALÁN SAULNIER, C., (1980): "Memoria de la primera campaña de excavación realizada en la Necrópolis de El Navazo (La Hinojosa, Cuenca)", Noticiario Arqueológico Hispánico VIII, 143 209.
GARCIA CANO, J.M.; PAGE,V; GALLARDO, J.; RAMOS, F.; HERNANDEZ, E. (2008): El mundo funerario ibérico en el Altiplano Jumilla-Yecla (Murcia): la necrópolis de El Poblado de Coimbra del Barranco Ancho. Investigaciones de 1995-2004. II. Las incineraciones y los ajuares funerarios. Murcia.

GARCIA JIMÉNEZ, G. (2011) El armamento de influencia La Tene en la Península Ibérica (siglos $V$-I a.C.). Tesis Doctoral inédita, Univ. Girona, IIII. s.l.

GARCIA JIMÉNEZ; G.; QUESADA SANZ, F. (2012 ep) "Los umbos bivalvos de scuta en Iberia y la cuestión céltica". VII Simposio sobre los Celtiberos. Nuevos hallazgos, nuevas intepretaciones. Daroca, 2012.

GARCÍA-SOTO MATEOS, E. (1990) "Las necrópolis de la Edad del Hierro en el alto valle del Duero." Necrópolis celtibéricas. II Simp. Celtíberos, pp. 13-38. Zaragoza.

GONZÁLEZ ZAMORA, C. (1999) Fíbulas en la Carpetania. Madrid.

GRAELLS FABREGAT, R. (2011) “Tres cascos italocalcídicos de la antigua colección Marqués de Salamanca en el Museo Arqueológico Nacional de Madrid". Oebalus VI, pp. 7-50.

GRAU MIRA, I.; REIG SEGUI, C. (2002-2003) "Sobre el uso de metales en la Contestania ibérica: las evidencias de La Serreta". Recerques del Museu d'Alcoi 11-12, pp. 101-150.

GUERIN, P. (2003) El Castellet de Bernabé y el horizonte ibérico pleno edetano. SIP Trabajos Varios 101. Valencia.

DE HOZ BRAVO, J. de (1994) "Una probable inscripción latina en un casco de Pozo Moro" Archivo Español de Arqueología, 67, pp. 223-227.

INIESTA SANMARTÍN, A. (1983) Las fíbulas de la región de Murcia. Murcia.

JACKSON, A. (1983) "Some deliberate damage to Archaic Greek helmets dedicated at Olympia." Liverpool Classical Monthly 8.2, pp. 22-27.

JARVA, E. (1995) Archaiologia on Archaic Greek Body Armour. Studia Archaeologica Septentrionalia 3, Rovaniemi.

JIMENO, A.; DE LA TORRE, J.I.; BERZOSA, R.; GRANDA, R. (1999) "El utillaje de hierro en Numancia y su información económica". F. Burillo (ed.) IV Simposio sobre Celtiberos. Economía, pp. 103-113. Zaragoza. 
JIMENO, A.; DE LA TORRE, J. I.; BERZOSA, R.; MARTÍNEZ, J. P., (2004): La necrópolis celtibérica de Numancia, Memorias de Arqueología en Castilla y León 12, Ed. Junta de Castilla y León, Valladolid.

JUNKELMANN, M. (2000a) Römische Helme. Sammlung Axel Guttmann, Band VIII. Mainz, Philipp von Zabern.

JUNKELMANN, M. (2000b) "Familia Gladiatoria. The Heroes of the Anmphiteatre". En E. Kohne, C. Ewigleben (eds.) Gladiators and Caesars, pp. 31-74. London.

KUNZE, E. (1967) “Chalkidische Helme”. Bericht über die Ausgrabungen in Olympia VIII, pp. 133183. Berlin.

LENERZ DE WILDE, M. (1991) Iberia Celtica. Archäologische Zeugnisse Keltischer Kultur auf der Pyrenaenhalbinsel. I-II. Stuttgart.

LORRIO ALVARADO, A.J. (1994) "La evolución de la panoplia celtibérica". Madrider Mitteilungen 35 , pp. 212-258.

LORRIO ALVARADO, A.J. (1999a) "Elementos para la delimitación de la Celtiberia meridional". F. Villar, F. Beltrán (Eds.), VII LCPPI, pp. 257-267. Salamanca.

LORRIO ALVARADO, A.J. (1999b) “Iberos y celtíberos en el Noreste de la Meseta Sur: evolución cultural y delimitación del territorio meridional de la Celtiberia". En M. A.Valero (ed.), las Jornadas de Arqueología Ibérica en Castilla-La Mancha, pp.103-127. Toledo.

LORRIO ALVARADO, A.J. (ed.) (2001) Los íberos en la Comarca de Requena-Utiel (Valencia). Alicante.

LORRIO ALVARADO, A.J. (2002) "Problemas de cronología en la panoplia celtibérica". P. Moret, F.Quesada (eds.) La guerra en el mundo ibérico y celtibérico, pp. 65-85. Madrid.

LORRIO ALVARADO, A.J. (2005) Los Celtíberos (2 ed.) Biblioteheca Archaeologica Hispana 25. Madrid.

LORRIO ALVARADO, A.J. (2007) "Celtíberos y bastetanos en el Oriente de la Meseta Sur: problemas de delimitación territorial". G. Carrasco (ed.) Los pueblos prerromanos en Castilla-La Mancha, pp. 227-270. Cuenca, UCLM.
LORRIO ALVARADO, A.J. (2008) "El armamento vetton." Zona Arqueologica 12, pp. 252-275.

LORRIO ALVARADO, A.J. (2012) "Procesos de continuidad y discontinuidad entre los oppida celtibéricos y las ciudades romanas en la Meseta Sur: los casos de Segobriga y Ercavica". G. Carrasco (ed.) La ciudad romana en Castilla-La Mancha, pp. 225-285. Cuenca, Univ. de Castilla-La Mancha

LORRIO ALVARADO, A.J.; ALMAGRO GORBEA, M.; SANCHEZ DE PRADO, M.D. (2009) El Molón (Camporrobles, Valencia). Oppidum prerromano y hisn islámico. S.l.

LORRIO ALVARADO, A.J.; SANCHEZ DE PRADO, M.D. (2009) La necrópolis celtibérica de Arcóbirga. Monreal de Ariza, Zaragoza. (=Caesaraugusta 80). Zaragoza.

LOSADA, H., (1966): La Necrópolis de la Edad del Hierro de Buenache de Alarcón (Cuenca), Trabajos de Prehistoria XX, Madrid.

MARTÍN MONTES, M.A. (1984) "La Fíbula anular hispánica en la Meseta Peninsular I. Origen y cronología, su estructura y clasificación tipológico". $B A E A A 19$, pp. 36-46.

MENA MUÑOZ, P. (1984) Catálogo de cerámicas de necrópolis de la Edad del Hierro del Museo de Cuenca. Boletín del Museo Provincial de Cuenca I. Cuenca.

MILLÁN MARTÍNEZ, J.M., (1988): “El yacimiento del Cerro de la Virgen de la Cuesta, entre el mundo del Hierro II y el mundo romano", Actas del 1 Congreso de Historia de Castilla-La Mancha III, Ciudad Real, 403-412.

MILLÁN MARTÍNEZ, J.M., (1990): “Una necrópolis tumular en Cuenca: Alconchel, II Simposium sobre los Celtíberos: Las Necrópolis, Zaragoza, 197-202

MILLÁN MARTÍNEZ, J.M., (1995): “La necrópolis del Cerro de la Virgen de la Cuesta (Alconchel de la Estrella, Cuenca)", El Mundo Ibérico: Una nueva imagen en los albores del año 2000, Junta de Comunidades de Castilla-La Mancha, Toledo, 246-250.

MORATALLA JÁVEGA, J. (1994) “La agricultura de L'Alcoià-comtat en época ibérica: datos para su estudio". Recerques del Museu d'Alcoi 3, pp. 121133. 
NAVARRO GASCÓN, J.V. (2008) “Análisis del metal en un casco ibero procedente del yacimiento arqueológico de 'Los Canónigos'. Informe inédito, Registro 23551. IPCE.

PASTOR EIXARCH, J.M. (2005-2006) “El casco celtibérico de la necrópolis de Numancia: ensayo de reconstrucción". Homenaje a A. Beltrán u R. Blasco, Kalathos 24-25, pp. 259-292.

PASTOR EIXARCH (2012 e.p.) "Un nuevo tipo de casco celtibérico". VII Simposio sobre los Celtiberos. Nuevos hallazgos, nuevas interpretaciones. Daroca.

PEREIRA SIESO, J.; CHAPA,T.; MADRIGAL,A.; URIARTE,A.; MAYORAL, V. (2004) La necrópolis ibérica de Galera (Granada). La colección del Museo Arqueológico Nacional. Madrid.

PÉREZ BLASCO, M.F. (2012 e.p.) "El Alto Chacón y su relación con el área ibérica de Levante en época sertoriana" VII Simposio sobre los Celtiberos. Nuevos hallazgos, nuevas interpretaciones. Daroca.

PÉREZ JORDÁ, G.; IBORRA, P.; GRAU, E.; BONET, H.; MATA, C. (2000) "La explotación agraria del teritorio en época ibérica: los casos de Edeta y Kelin": R. Buxó, E. Pons (eds.) Els productes alimentaris... Actes XXII Colloque de l'AFEAF, pp. 151-167. Girona.

PÉREZ JORDÁ, G. et alii (2011) "El trabajo cotidiano. Los recursos agropecuarios, la metalurgia, el uso de la madera y las fibras vegetales". H. Bonet, J. Vives-Ferrándiz (eds.) La Bastida de les Alcusses 1928-2010, pp. 94-137. Valencia.

PLA BALLESTER, E. (1968) "Instrumentos de trabajo ibéricos en la región valenciana." M. Tarradelll (Ed.), Estudios de Economía ibérica de la Península Ibérica, pp. 143-190. Barcelona.

QUESADA SANZ, F. (1997) El armamento ibérico. Estudio tipológico, grográfico, funcional, social y simbólico de las armas en la Cultura Ibérica (siglos VI-I a.C.). Monographies Instrumentum 3, Montagnac. Ed. Monique Mergoil.

QUESADA SANZ, F. (1997b) "Gladius hispaniensis: an archaeological view from Iberia". L'équipement militaire et l'armement de la République. JRMES 8, pp. 251-270.
QUESADA SANZ, F. (1998): "Aristócratas a caballo y la existencia de una verdadera 'caballería' en la cultura ibérica: dos ámbitos conceptuales diferentes". C. Aranegui (ed.) Los Iberos, príncipes de Occidente. Actas del Congreso Internacional, Barcelona, pp. 169-183.

QUESADA SANZ, F. (1999) "Porcuna, Cástulo y la cuestión del supuesto carácter meseteño, indoeuropeo o céltico de su panoplia: el 'armamento ibérico' como armamento ibérico". Actas del II Congreso de Arqueología Peninsular, Zamora 1996, vol. III, pp. 425-434.

QUESADA SANZ, F. (2002-2003) "Mirando el mundo desde lo alto: espuelas y otros elementos asociados al caballo en el poblado de La Serreta de Alcoi". Recerques del Museu d'Alcoi 11-12, pp. 85-100.

QUESADA SANZ, F., (2005): "El gobierno del caballo montado en la Antigüedad Clásica con especial referencia al caso de iberia. Bocados, espuelas y la cuestión de la silla de montar, estribos y herraduras", Gladius XXV, 97-150.

QUESADA SANZ, F. (2006) "Resistencia numantina". La Aventura de la Historia 93, pp. 79-83.

QUESADA SANZ, F. (2010) Armas de la antigua Iberia. De Tartesos a Numancia. Madrid, La Esfera.

QUESADA SANZ, F. (2011) "The Braganza Brooch warrior and his weapons: the Peninsular context". A. Perea (ed.) La fibula Braganza, pp. 137-156. Madrid, CSIC-Polifemo.

QUESADA SANZ, F.; GABALDON, M.; REQUENA, F.; ZAMORA, M. (2000) “¿Artesanos itinerantes en el mundo ibérico?. Sobre técnicas y estilos decorativos, especialistas y territorio". C. Mata, G. Pérez (eds.) Ibers. Agricultors, artesans i comerciants, Saguntum Extra 3, pp. 291-301. Valencia.

RAMS BROTONS, M.V. (1975) "Avance a un estudio de las fíbulas ibéricas de la prov. de Valencia". Archivo de Prehistoria Levantina 14, pp. 139153.

REY OSORIO, A. del (2008) "Informe sobre el estado de conservación y restauración de un casco de bronce del yacimiento arqueológico de Los Canónigos. Arcas del Villar. Cuenca”. Informe inédito, Registro 23551. IPCE. 
ROBINSON, H.R. (1975) The Armour of Imperial Rome. London.

SANAHUJA, M.E. (1971) "Instrumental de hierro agrícola e industrial de la época ibero-romana en Cataluña." Pyrenae 7, pp. 61-110.

SANZ GAMO, R.; LOPEZ PRECIOSO, J.; SORIA COMBADIERA, L. (1992) Las fibulas de la Provincia de Albacete. Albacete.

SANZ MÍNGUEZ, C. (2002) "Panoplias prerromanas en el centro y occidente de la Submeseta norte peninsular". P. Moret, F. Quesada (eds.) La guerra en el mundo ibérico y celtibérico, pp. 87-133. Madrid.

SCHÜLE, W. (1969) Die Meseta-Kulturen der Iberischen Halbinsel. I-II. Berlin.

STARY, P.F. (1986) "Italische Helme des I. Jahrtausends vor Christus". J. Swaddling, Italian Iron Age Artefacts in the British Museum, pp. 3742. London.

TAGLIAMONTE, G. (2002-2003) "Dediche di armi nei santuari sannitici". M. Bendala, P. Moret, F. Quesada (eds.), Formas e imágenes del poder.. CuPAUAM 28-29, pp. 95-125. Madrid.

TAGLIAMONTE, G. (2003) "Note sulla circolazione degli elmi nell'Abruzzo e nel molise preromani". MEFRA-Antiquité 115, pp. 129-175.

TARACENA AGUIRRE, B. (1932) "Excavaciones en la Provincia de Soria" MJSEA 119. Madrid.

VALERO TÉVAR, M.A. (ed.) (1999) Primeras Jornadas de Arqueología Ibérica en Castilla-La Mancha. Iniesta (Cuenca), 2-4 Mayo 1997. Toledo.

VALERO TÉVAR, M.A., (2007): Carta Arqueológica del Término municipal de Arcas del Villar, Documento inédito depositado en la Consejería de Cultura, Turismo y Artesanía de la Junta de Comunidades de Castilla-La Mancha, Toledo.
VALERO TÉVAR, M.A., (2010a): “El yacimiento ibérico de Los Canónigos (Arcas del Villar, Cuenca)", Nuestro Patrimonio. Recientes actuaciones y nuevos planteamientos en la provincia de Cuenca, Excma. Diputación Provincial de Cuenca, 161-182.

VALERO TÉVAR, M.A., (2010b): “La necrópolis ibérica de la Punta del Barrionuevo, Iniesta-Cuenca. Avance de las últimas investigaciones", Actas de las II ${ }^{a}$ Jornadas de Arqueología en Castilla-La Mancha, Excma. Diputación Provincia de Toledo, Toledo, 1010-1045.

VALERO TÉVAR, M.A. (2012a): El yacimiento ibérico de Los Canónigos (Arcas del Villar, Cuenca) y su aportación al proceso de iberización en la Sumbeseta Sur, ADIF-Ministerio de Fomento, Valencia.

VALERO TÉVAR, M.A. (2012b): “El yacimiento ibérico de Los Canónigos, Arcas del Villar (Cuenca): un nuevo asentamiento en la supuesta frontera meridional de la Celtiberia", En BURILLO, F., (Ed.), VII Simposio sobre celtíberos (Daroca 2012), Zaragoza, 183-195.

WARMENBOL, E. (1983) "Ils ont plié armes et bagages... Quelques reflexions au sujet des épées ployées trouvées en Syrie et au Liban". Studia Phoenicia I-II. OLA 15, pp. 79-89. Leuven..

WAURICK, G. (1988) "Römische Helme". En Antike Helme, pp. 327-364. Mainz, RGZ.

WEISS, C. (1977) "An unusual Corinthian Helmet". California Studies in Classical Antiquity, 10, pp. 195-209. 

